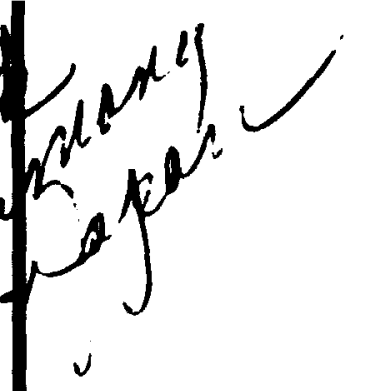

H. 3SPE

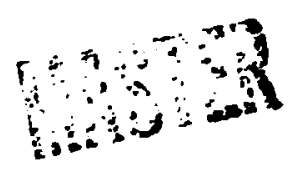

Substructures Developed During Creep and Cyclic Tests of Type 304 Stainless Steel (Heat 9T2796)

R. W. Swindeman

R. K. Bhargava

V. K. Sikka

J. Moteff 


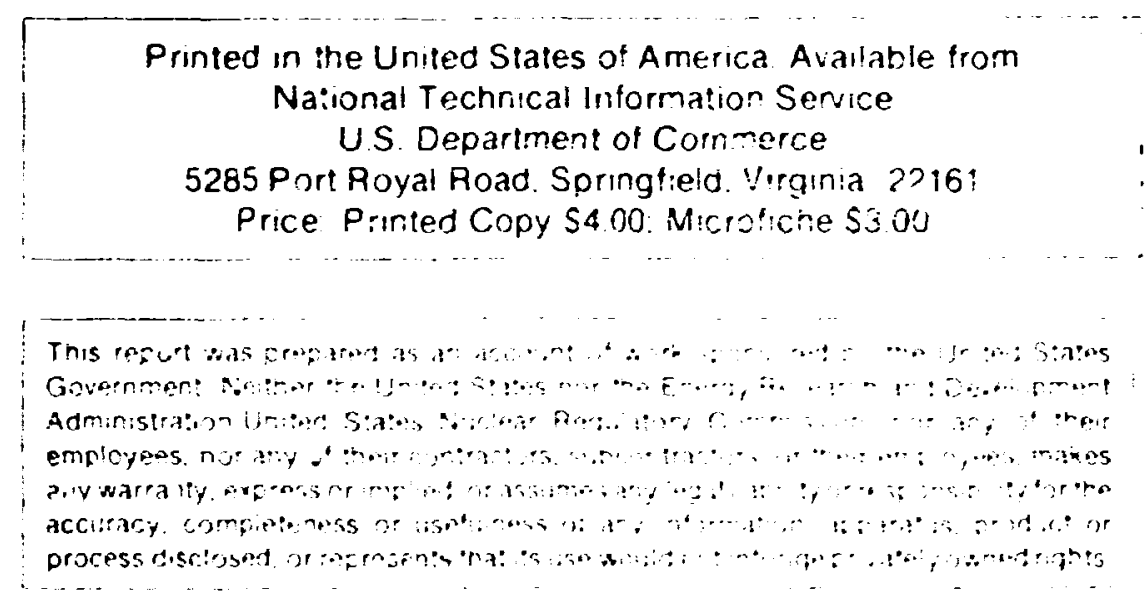




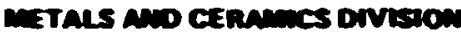

\section{SUESTRUCTURES DEVELORED DURING CREEP AWD CYCLIC TESTS OF TYIE 304 STANLESS STEEL (HEAT 9T27SS)}

R. W. Swindeman

A. K. Bhargera

V. K. Sikka

J. Moteff

Date Published: September 1977

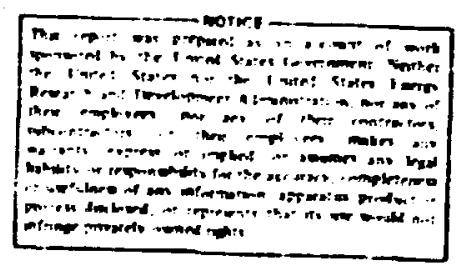

OAK RIOGE MATIONAL LACOAATOAY

Oun Rives. Ten.nosion 37030 aperomed by UNION CAREADE COANOAATION

for ine

ENERGY RESEANCH AND DEVELOMENT AOMUNSTMATLON 


\section{CONTENTS}

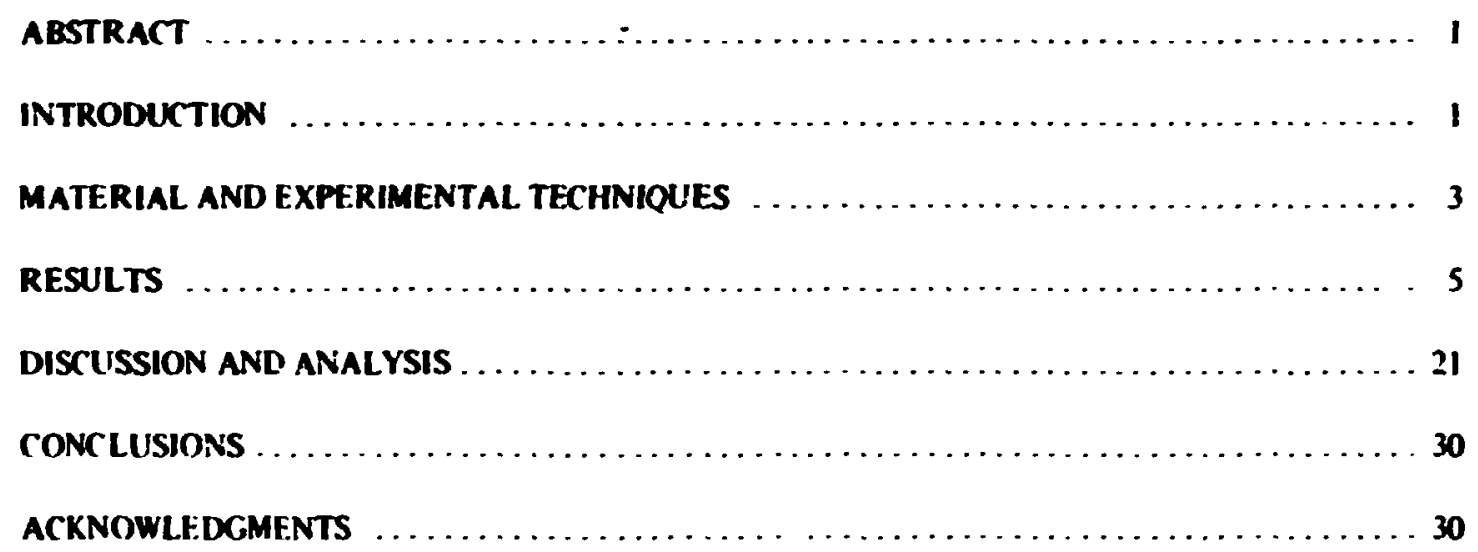




\title{
SUBSTRUCTURES DEVELOPED DURING CREEP AND CYCLIC TESTS OF TYPE 304 ST AINLENS STEEL (HEAT 9T2796)*
}

\author{
R.W. Swindeman V.K. Sikka \\ R. K. Bhargav:" J. Moteff'
}

\begin{abstract}
Sebstructures developed in rester pecimens of a reference heat of type 304 staindexs stecl iheat

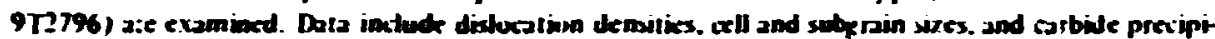

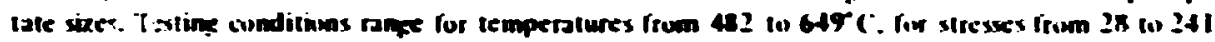

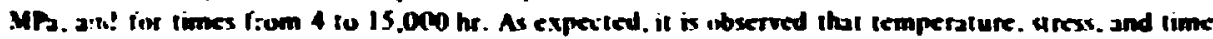
hove strung influenes on substructure. The chape in the diskocation density is tive small to measure for cunditions which produce les than 17 mexasuain stram. No cells furm. and the majur alteration

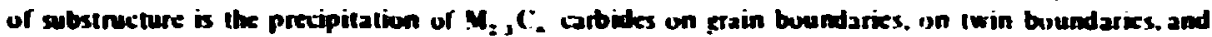
on some distucativas. Al stresses ranging from 69 (1) 172 MPs and at temperatures sanging from 482 to $593^{\circ} \mathrm{C}$. the diskcation clensity inereases with increasing stress and is perkerally higher than expectod

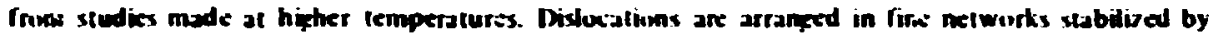

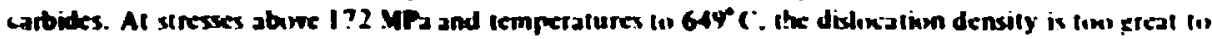
measure. Cells develey which are finer in size than cells developed at similar siresses but at hizher temperatures. Dishriation densitics and cell sixes for cyclix specimens are ciomparable to data fior

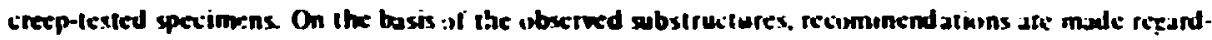
ing further studies which would assist in the development of constitutive equations lier hiphtemperature inelastic analysis oll reacior compennents.
\end{abstract}

\section{INTRODUCTION}

Currently recummended constitutive relations for use in the inclastic analysis of liçuid-metal fast breeder reactor (LMFBR) components'.2 are based on :he asumplion that mechanical strain can be separated into three components: elastic, time-Hi.l.pendent plastic, and time-dependent creep. Specific :onstilutive relations which provide rules for describing the yield. flow. and hardening behavior are formulated separately for plasticity and ireep. Ad hox rules. which arc iniended to compensate for creepplasticity interactions. are also provided. The eyuations are based primarily on concepts involving principles of continuum mechanics, thermodynamics. and rheology. although results fr. 2 m exploratory mechanicalproperty studies are also considered. ${ }^{3}$ Nihough these constitutive equations have ')een accepted and are in use." the Strucitural Design Methods (SDM) program" at the Oak Ridge Nation:l Luboratory (ORNL) is organized on the premise that the inclastic design methods shouid be upgraded perindically through an

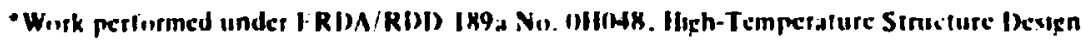

tiniversity ir Cincinnati

1. C. I. Pueh el al.. Currently Recommended Comstifurive fiduations for Inelastic Design Analysis of FFTf

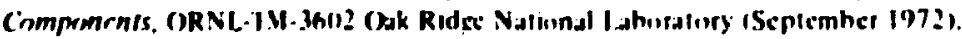

2. C. F. Pugh el al. Backemund Infomotinn for Inierim Bethods of Inelostic Andysis for High-Temperature Reacion Componenis of 2\% Cr I Mo Sirel. OR NL/TH.5226. Oak Rudpe Nalicnal L.aburatury (1976).

3. J. M. Corum $\mathrm{r}$ ial. Pressure lessels and Piping: Verification and Qualificarion of Inelastic Anelysis Compuler

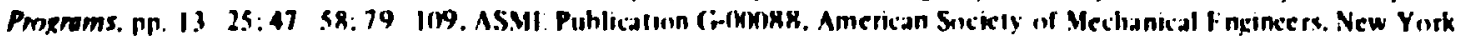
(Jine 1975).

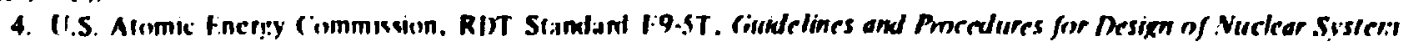
Components af tilevaled Temperalures. Oak Ridpe Nalinnal I.ahniralury (Warch 1074;

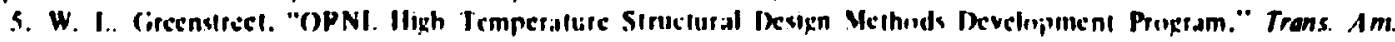
Nucl. Soc. 1(2): 4m I, Novemher 197.3). 
ilerative process which requires a close interaction between material studies. constitutive equation development, computational methods de velopenent, and structural tess. The development of impromed constitutive equations. for example. clearly requires an improved knowledes of material behavior.

Recently. Robiuson and comorkers" have initiated work to develop improved constitutive equations for we in the LMFBR program. Under consideration are approaches propused by Itart, Onat," Rlie." Lagneborg." and Miller." These last three investigators consider the fact that polycrystalline alloys deform principally by the movement of line defects (dislocations). However, in a commercial alloy, such as type 304 stainkess steel at an elevaled temperature, strong interactions occur between dislocations and point defects, such as interstitists and substitutional atoms. These interactions impede distocation gliste and climb. Abo, as shown by Croasman and Achby' ${ }^{2}$ and Mohamed and Langdon," ${ }^{3}$ one can atso expect that at low creep-strain rates. significant deformation can resalt from grain boundary sliding and diffusion creep, which do not necessary involve distocation motion in the matrix. Finally, it is known that the presence of precipitates. such as $M_{2}, C_{6}$. has a profound influence on the distocation substructure ${ }^{14}$. is and hence. on mechanical behavior. These metallurgid complications have not been considered in the development of many of the deformation models adranced for predicting iselastic behsvior of structural materiats under arbitrary the rmal and mechanical loadings. It would seem desirable, therefore, to characterize distocation structure and to use such infornvation as a guide in the setection of deixmation modets. The potential of this approach has been demonstrated recently by Lagneborg and coworkers. : $a .17$

The work presented here represents an evaluation of dist siation substructures and carbide distributions in tensile, creep, and cydic-tested specimens of type 304 stainless steel. The studies were supported by several ERDA programs, including a program at the University of Cincinnati on the Correlation of Strength and Microstructure (CSM) (ERDA contract no. AT-101 I); and programs at Oak Ridge National Laboratory on the Generation and Correlation of Deformation and Failure Criteria for Structural Materials (DFCSM) (ERDA 189a OHOSO), and the Development of Improved High-Temperature Inelastic Structural Design Method (SDM) for LMFBR Cemponents (ERDA 189a Aztivity No. OHD48). In general, the specimens which were studied were not tested specifically to provide material for substructure investigations. Rather. the original intent was to produce mechanical properties data. Although the description of the thirty-six

6. D. N. Robinson, A Comdiduse Creep-Recowery Model for $2 \% \mathrm{Cr}$-I Mo Steel and Its Fixperimental Implementoriom. ORNL.-3 M-SI 10, Oak Ridae National Laboratory (Detober 1975).

7. F. W. Harl, "A Thenomenological Theory for Pastic INeformation of Poblycrystalline Mctals." Acro Merell. is $599-610(1970)$.

8. F. T. Onal and F. Fardshisheh, Representorion of Creep of Menels, ORNL-4783. Oak Ridge Natiunal l.aburalır; (August 1972).

9. J. R. Rice, "On the Structure of Stress-Sirain Rebions for Time-Dependent Mastic Deformation in Metals," Thase ASME. Ser. F. J. Appl Mech., 37: 728 . 37 (1970).

10. R. Lagneborg." A Modifed Recovery-(ireep Model and Is Fivalualion." Met. Sci. J., 6: 12733 (1972).

II. A. K. Miller. "An Inelastic Constitutive Model for Monotoric. Cycle and Creep Deformalion: Part I. Fquations Development and Analy tical Procedures: Part II. Application to Type 3n Stainlexs Stecl." Trans. A.SME. J. Feng. Morer. Technol, 98: 97-113 (1976).

12. F. W. Crossman and M. F. Ashby. "The Non-uniform Flmw of Polycryslals by Grain-fioundary Stiding Accommodaled by Power-Law Creep." Acre Mered., 23: 425-40 (1975).

13. F. A. Mohamed and T. G. Langdon, "Deformation Mecharissm Maps Based on Grain Sizc." Metoll. Trans. S 2339-45 (1974).

14. J. T. Damby, "Efrect of Strain Aging on the Hightr-Temperature Tensile Properties of an AISI 316 Ausienitic Stainiess Steel," J. Inon Sreel Inst. London, 203: 392-65 (I965).

15. F. Garofalo, Fundomenads of Crepp and Creep Ruprure in Merds, MacMillan Co.. New York. 1965.

16. R. Lagneborg B-H. Forḱn, and J. Wiberg. "A Recovery-Creep Model Based Upon Dislocation Distributions." pr. I -7 in Creep Smength in Sied and High Temperafure Alloys. The Mctals Sociely. I.ondon. 1974.

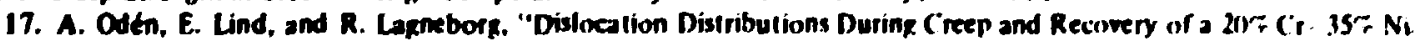
Steal al 7006.," pp. 60-66 in Creep Sirengeth in Sicel and Hish Temperature 4lloys. The Metals Siniety. I.nndon. 1974. 
Iransmissionetectron micrugraphs reproduced in this repurt makes the reading somewnit iedious. the reader should take comfort in the fait that two hundred other sazilsble mierograpts werc not included.

\section{MATERIAL AND EXTERIMENTAL TECHNGOUES}

The materiai examined was laken from a 25-mmithick plate of a well-characterized heat of lype 304 stainkess steel (heat 9T2796). " Uniaxial test bass havig diameters near $6.35 \mathrm{~mm}$ were maxhined from the plate, reannesled for $0.5 \mathrm{hr}$ at $1093^{\circ} \mathrm{C}$, and tested is tensik, creep, and strain-iycling modes. All tensike lests were performed in air with techniques described elsewhere." Although some tensike tests were discuntiaued at low strain kevels, all the specimens examined here were lested to complets failure.

Creep tests were atso performed in ait using techniquas described by Swindeman and rugh. ${ }^{20}$ Specimens wnich were examined included some on wtich lests were discontinued in different stages of ereep. and somk on which tests were continued to failure. When tests were discontinued, the load was maintained until the specimen was cool.

Tixe experimental tecturiques used for cyclic testing have not been described meviously. The specimen design and experimental setup ae shown in Fig. 1 . The cyclic specimers had a triform length of $25 \mathrm{~mm}$.

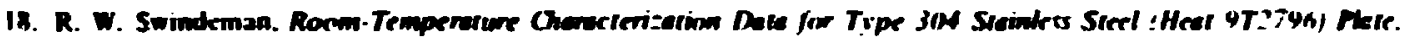

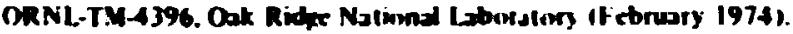

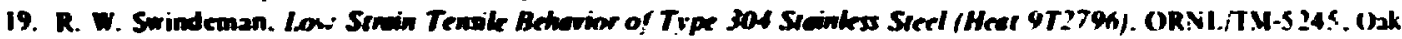

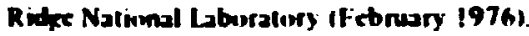

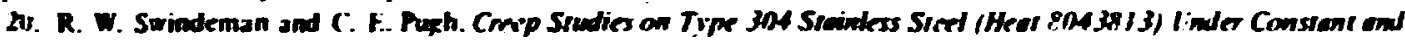
Verving Lods. ORNLTM 427. Oak Ridec Natwonal Loboratory (Juik 1974).

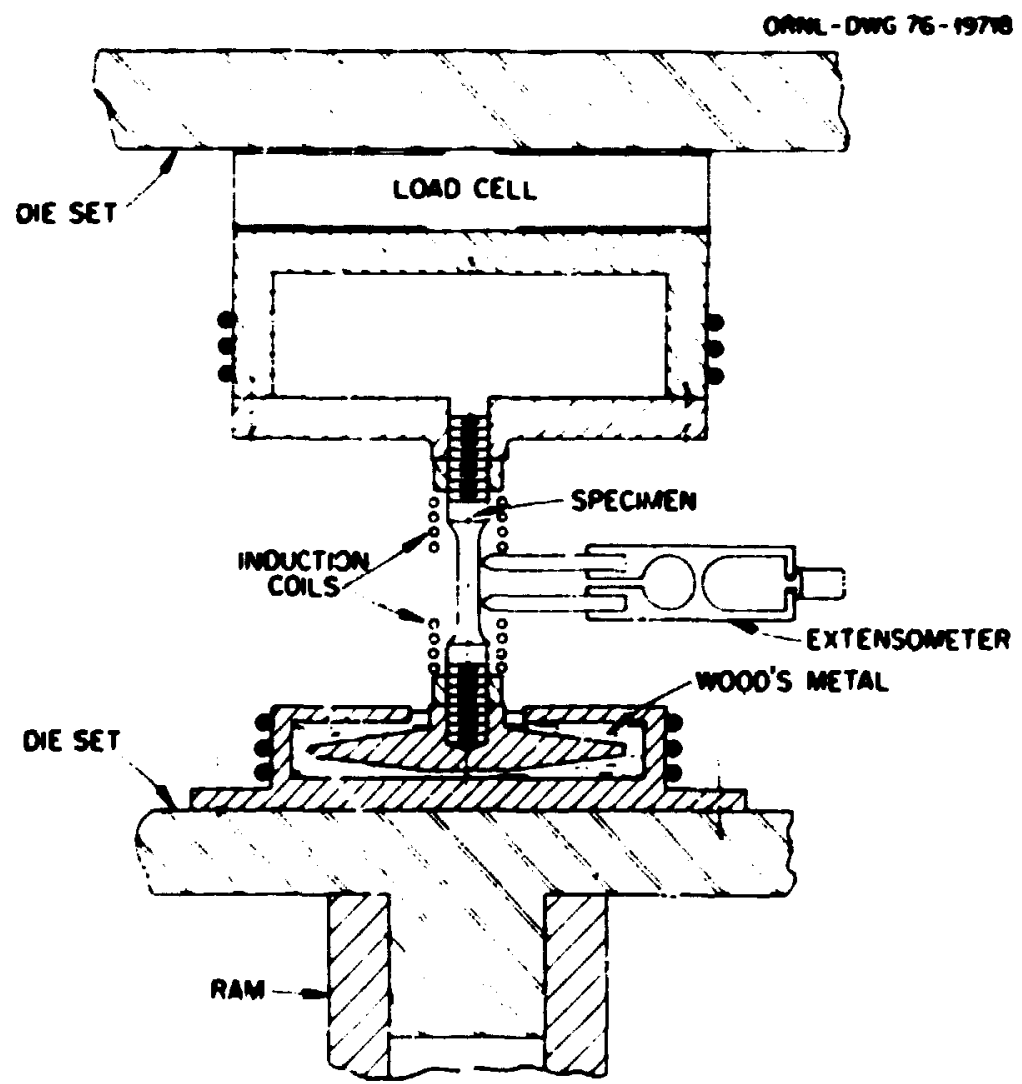

Fip. 1. Schematic drawing of setup for strin cy cling. 
about $10 \mathrm{~mm}$ of which was actwally used for control of temperature and cycticstrin range. The experimental setup was similar in many respects to the one wed by Jaske et al." ' Cyctic speciniens were nut rested to failure, but rather to cyclic lives which epproacted the values necessary to establish saturation conditions. Each teat was terminated by unioeding the specimen when it was halfway through the tensibe portion of the hysteresis loop and then couling the pecimen to roun temperature.

Specimens for transuissionelectron microscopy (TEM) were prepared by cutting transverse sections from beations near the center of discontinued specimens or stightly away from the rupture surface of failed specimens. The diameters of stices were measured and used to determine the true stresses. The foils for TEM were prepared by mechanically thinning to foil thictnesses near $1 \mathrm{~mm}$ and by fmal electropolishing uing a isinjet polsher and an electrolyte of $90 x$ acetic acid and $10 \%$ perctionic acid. ${ }^{22}$ Several foils were examined when possible, and severd areas of each foil were examined. Typically, micrographs of four to six areas were avilable for quantitative measurements.

The data base from which specimens were selected for this study is summanized by the matrix shown in Fig. 2. Temperatures range frum 427 to $816^{\prime \prime} \mathrm{C}$ and stresses from 35 to $414 \mathrm{MPa}$. The filled circles represent creep specimens studied in this work, and the fill anures represent creep specimens studied eartier. 22 . 24 The filked triangles represent tensiketssted specilions studied earlier. The open symbots represent test

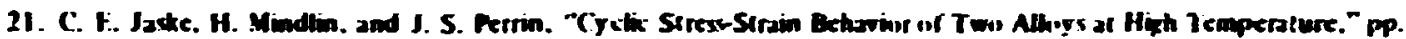

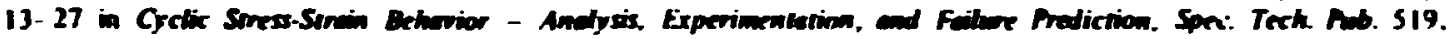
American Sociely fier Textiog and Malerials. 1973.

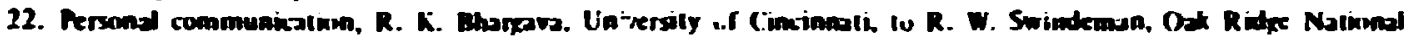
Loboralery. 1975.

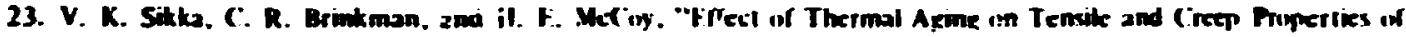

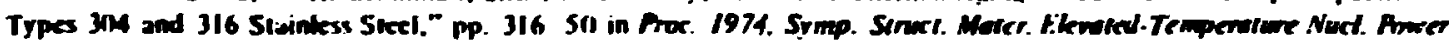
Ciemention Senvice, ed. A. O. Schoctier. Mr... 1975.

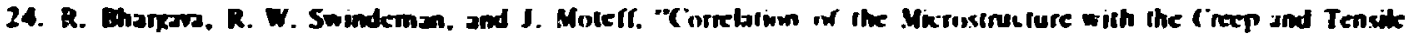

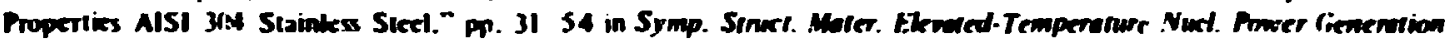
Senvice. d., A. O. Schatfer, MrC:1. 1975.

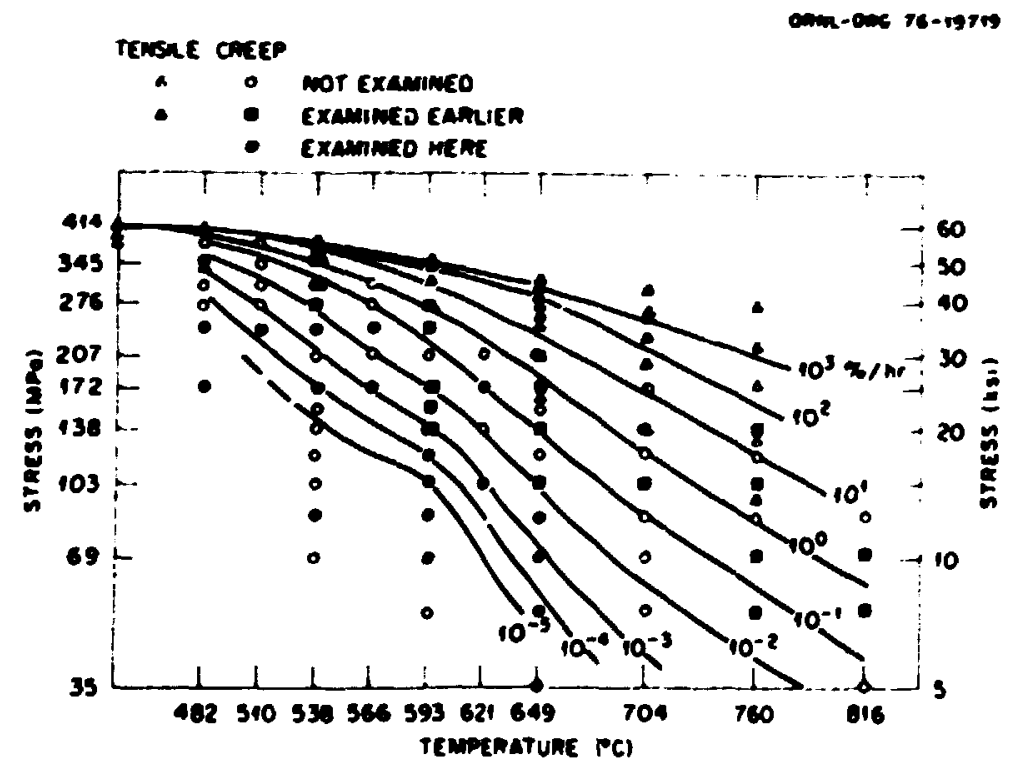

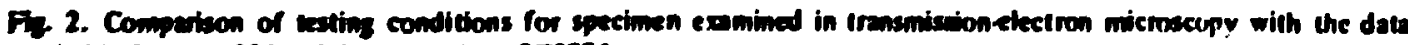

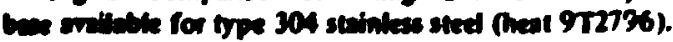


specimens which were nut examined. Siperimpused un the malnix are curves which represent the sreep strength $n$ iemperature for secondary creep rates sanging firom $10^{-3} 1010^{3}$ percint per hr. Figure 2 shows that specimens were setected fior the examination of temperature effects at cunstant stress (fior e.cumple. at 241. 172. and $103 \mathrm{MPa}$ ): stress eflects at constant temprerature (for example. at $538.543^{3}$, and $649^{\circ} \mathrm{C}$ ): and stress-emperature effects at constant creep rate (fior example. at $10^{-2} \cdot 10^{-3}$. and $10^{-4}$ perient per br). The specinens included in this work (filled circks in Fig. 21 generally innulved examination at lower temperatures than thuse in earlier studies.

\section{RESULTS}

Data generated at the University of Cimeinati under the support of the SDM program are summarized in Taite 1 . Induded are data relating to the average cell or subgrain sixe $(\lambda)$, the average distocation density (p). and the size of the grain boundary and of the matrix carbides. In expanding the intormation contained in Table 1, we make use of data for the same material generated in the other programs described in the introduction. The information is organized on the basis of isothernul data. starting at the lowest temperature, $482^{\circ} \mathrm{C}\left(900^{\circ} \mathrm{F}\right)$, and moving upward. At each temperalure we slart with the lowest stress. considering al each stress level the shortest time first, then the longet times. Thus, we are ex=mining the influence of incteasing lemperalures, increasing stresses (or plastic strains). and : ncreasing times for creep strairs).

The initial microstructure is shown in Fig. 3 . This consists of a low densily of distorcations (approximately $10^{\circ} \mathrm{cm}^{-2}$ ) more or kess randomly distributed throughout the șains. The grain size is approximately $180 \mathrm{\mu m}$. and the grain boundaries are free of precipitales." There is sime ividence of dislixiations piled apanst or eminating from the boundaries in a few cases. Must dislocations are lairly straight. and there are few tangles, loops, or dipotes.

The first dala listed in Table I are from a specineen IRP I25) testell at 17: MPa fior 1580 hr. The lest was discontinued after the specimen experienzed about 5 ro loading st pin and 0.03 r creep strain. A typical TEM is shown in Fig. 4. and as can be seen. the distocalions $17.55 \times 10^{\circ} \mathrm{cm}^{-2}$, lie primanly on slip iraces (III planes). There are quile a lew curved disliciztions and sume tangles. lionps. and dipoles. No dear evidence of dislociation uells or subgrains exists. Possibly this struxture has heen produced by planar slip during plastic loading. followed by cress slip and glick of disfications out of the slip plane during the period of ereep. There is no evidence of precipitalion in either the grain boundaries or the matrix at the ragnifica. tions which were employed $(20.000 \times)$. This is consistent with the finding of Sikka of al. "3 on material aged al $482^{\circ} \mathrm{C}\left(900^{\circ} \mathrm{F}\right)$.

The seciond data listed in Table 1 cumes from a specinen (RP 267) tesied al $482^{\circ} \mathrm{C}$ and $241 \mathrm{MPa}$. This specimen experienced about $K \%$ lkading strain and abuut $0.06 \%$ creep strain. The specimen did not rupture. The substruclure shown in fig. 5 differs markedly from the subsiructure developed at lower stress (fig. 4) and consists of 2 high density of dislociations which are langled in a configuration of pororly definel cell walls. The average sell dimension is eslimaled at $0.72 \mu \mathrm{m}$. The cellular structure seen in Fig. 5 is a result of the large plastic loading strain and is morc a manifestalion of dislociation glide and dynamic recovery processes which involve cruss slip than a manifestation of dislocalion climb and thermal recovery. Although nu grain boundary precipitates are observed. a few localired needles whicl could be $M_{2}{ }_{3} C_{6}$ carbides are present. The major dimension of the needles is near $0.5 \mu \mathrm{m}$.

Data for one specimen (RP 324). tested al $510^{\circ} \mathrm{C}:\left(150^{\wedge} \mathrm{F}\right.$ ) and $241 \mathrm{MPa}$, are reprotied in Table 1 . This specimen experienced about 10.4\%: loading strain and failed in $3511 \mathrm{hr}$. The suhstruclure which developed in this specimen (fiig. 6) consists of purtly ilelined cells. having an intercept dimension near 0.9? $\mu \mathrm{m}$. and being aligned more or less along cystallographic planics. The dislocation density is aot teported but appears 


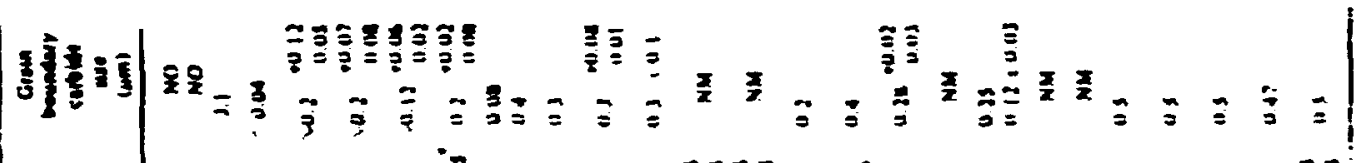

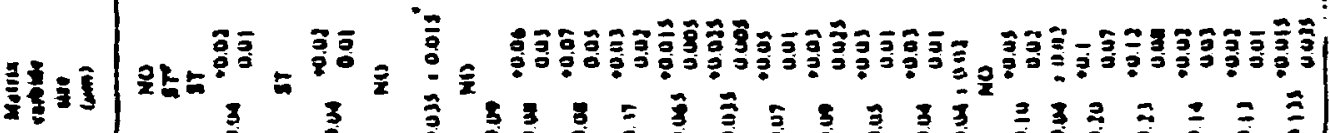

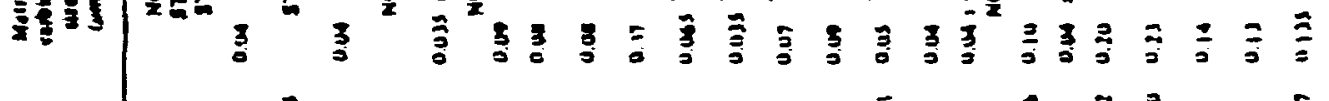

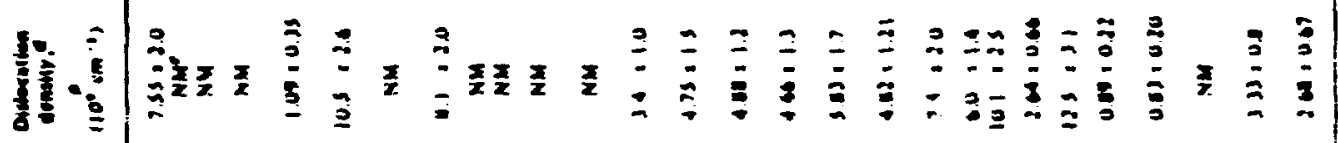

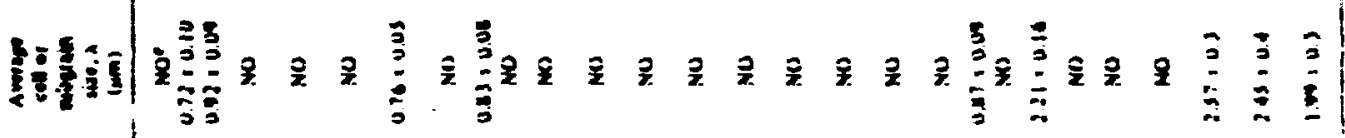

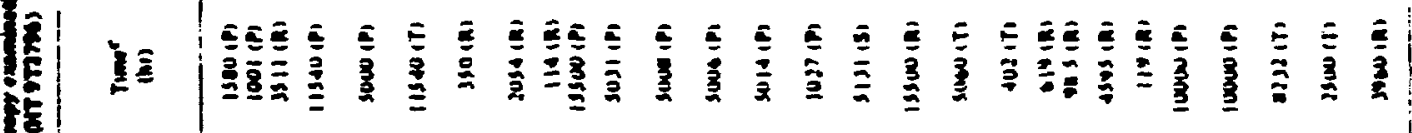
1 |

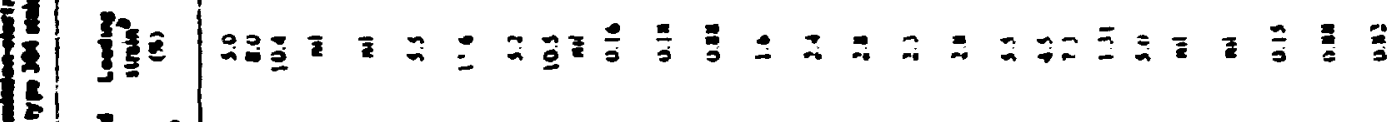

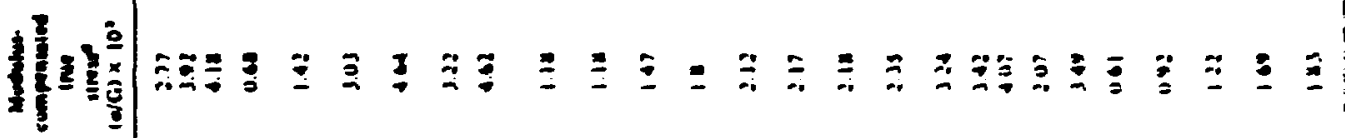
㝵彭 竞

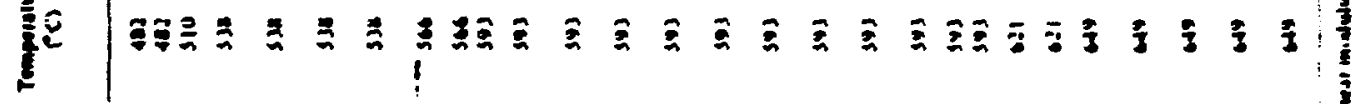
II 


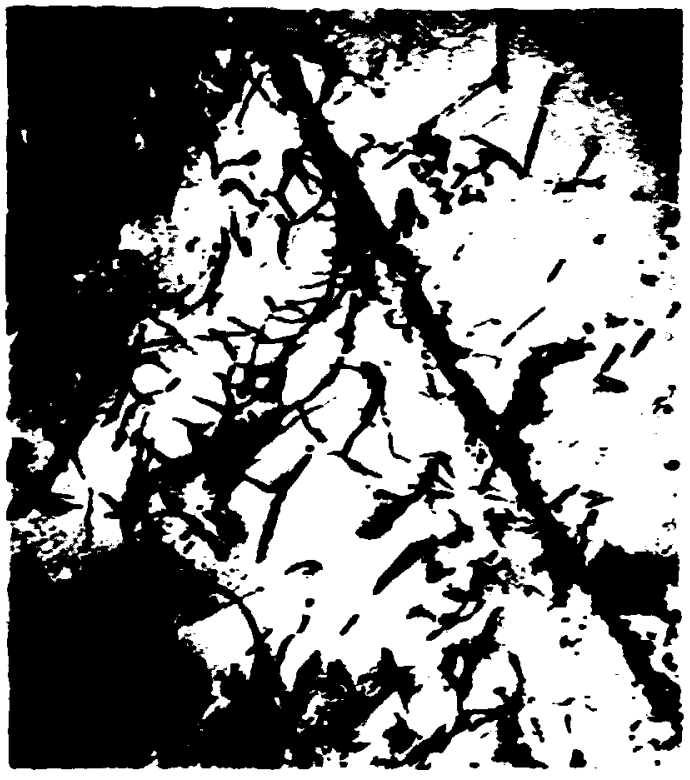

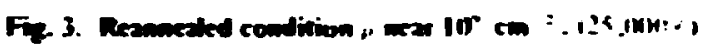

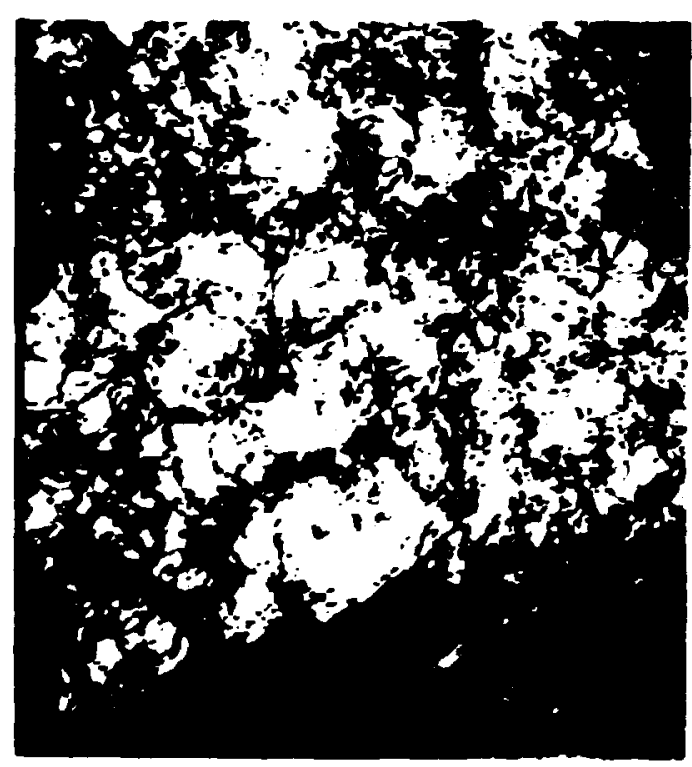

Fig. S. RP 267 tested at th2 c at 24 YPa fin IOOI hr. experiencing $8.06 \%$ strain. $x$ in.t. $1,7.2 \mathrm{~mm}$

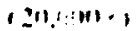

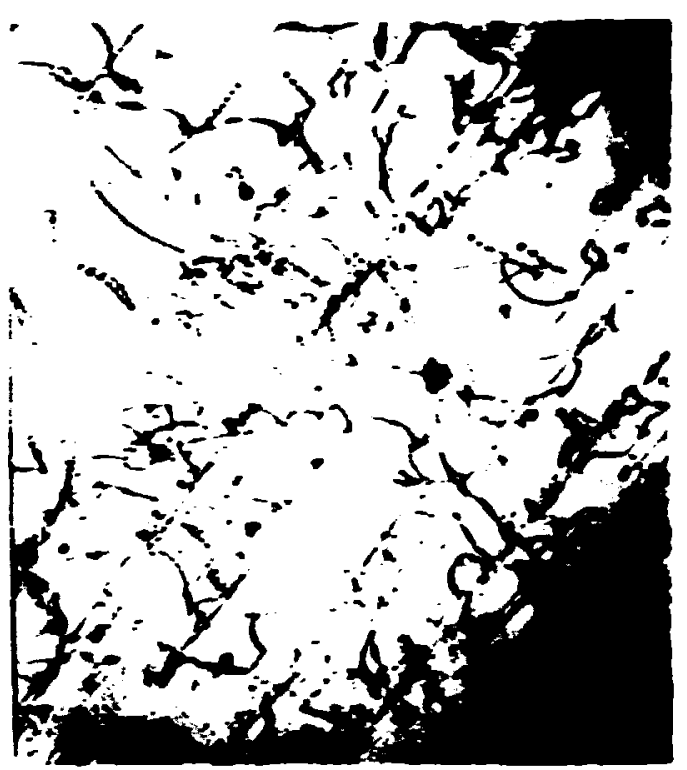

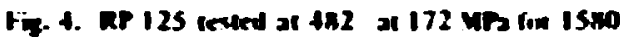

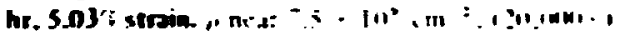

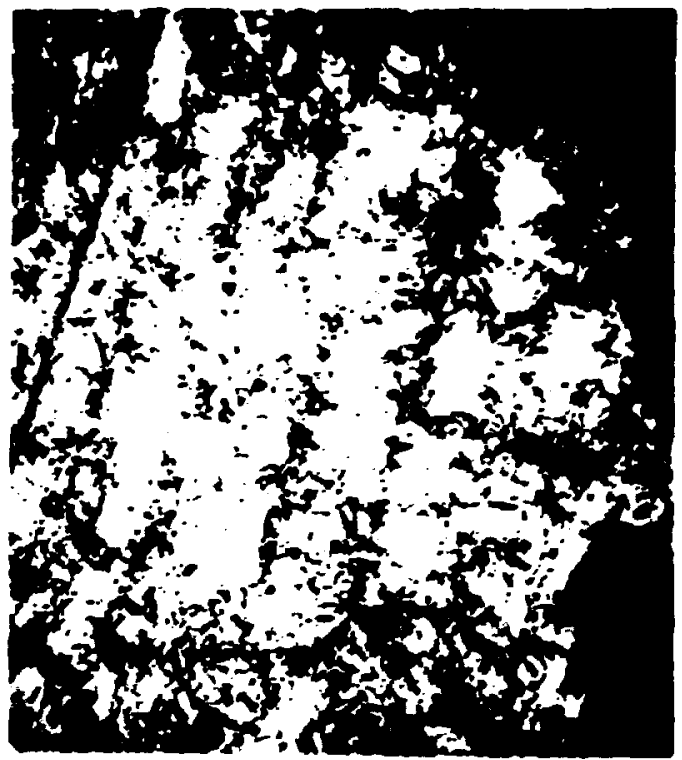

Fig. 6. RP 324 lesied al SIO ( at 241 VPa for 351 I hr. experinencim 12.9: strain. : ne, $11 "$ " $\mathrm{mm}$ , $15,1 \mathrm{ml1} \cdot \mathrm{s}$ 
qualitatirely to be similat to the densily observed in the high-stress specimen (RP 267) tested at $482^{\circ} \mathrm{C}$ and shown in Fig. 5 . As before, the substructure is developed primarily from the large plastic loading strain which produced dislocation glide, cross slip, and associated dynamic recovery. Precipitation of carbides occurs on the grain boundaries at this temperature, however, and a typical size is near $0.1 \mu \mathrm{m}$. There is also some evidence of matrix carbides. These are few, localized, and near $0.1 \mu \mathrm{m}$ in size.

At $538^{\circ} \mathrm{C}\left(1000^{\circ} \mathrm{F}\right)$, the substructures derelupad at eight stress ievels have been examined. Two stress levels (specimens RP 14 and RP 201) were produced by tensile testing. These and several creep specimens have been examined under the sponsorship of a different program (CSM) and data are not included in Table 1. The substructure for the lowest stress (near $41 \mathrm{MPa}$ ) listed in Table 1 was produced in the shoulder region of a specimen (RP 78) tested at $172 \mathrm{MPa}$ for $11,540 \mathrm{hr}$. This substructure is shown in Fig. 7 and exhibits the same distocation density as the untested specimen. The dislocations are straight, exhibit attractive junctions, and are decorated by precipitates approximately 0.03 to $0.06 \mathrm{~mm}$ in size. The cell size is the same as the grain size. Precipitates also lie on the grain boundaries and appear to be of the same size as matrix precipitates. These precipitates are atsociated with boundary dislocations.

The next stress level examineci at $538^{\circ} \mathrm{C}\left(1000^{\circ} \mathrm{F}\right)$ is $86 \mathrm{MPz}$ (specimen RP 264). The specimen experienced no plastic loading strain, but accumulated about 0.06 creep strain before the test was disimtinued at $5000 \mathrm{hr}$. There is no evidence in Fig. 8 of subgains. and the dislocation density $\left(1.09 \times 10^{\circ}\right.$ $\mathrm{cm}^{-2}$ ) is cluse to the starting value. The dislixations are arranged in networks having buth attractive and repulsive junctions. ${ }^{9.25}$ Curved dislocation segments appear :o be free of precipitites. There is seme evideme that fire precipitates are present on sume matrix dislocations, as is the case for the shoulder region of spicimen RP 78. desciribed above. These precipitates are sbuut $0.02 \mu \mathrm{m}$ in size.

The section of specimen RP 78 which was stressed to 172 MPa experienced abuut $5.5 \%$ plastic loading strain and 1.9\% creep strain before the test was discontinuied in the tertiary creep stage. The dislocation substructure shown in Fig. 9 can be best described as a dense dispersion of tangles and networks. There are nume:ous repulsive junctions, loops, and dipoles. The substructure appears to be stabilizert by carbide precipilates, shown in Fig. 10. All evidence of the planar slip produied during loading has been destroyed. Some relatively clear areas among the tangles might be considered as intercell regions, however. The dislocation density is about one order of magnitude above tine initial value. and tne substructure does not sugeest that thermal recovery processes are very active. It is clear that the carbide dispersion is fine enough to play a role in determining the time-dependen:t behavior.

The final data in Table 1 for $538^{\circ} \mathrm{C}$ describe the substructure developer in a specimen stressed to 241 MP. The plastic loading strain is $11.8 \%$, and the creep strain about $6.4 \%$. The specimen failed in $350 \mathrm{hr}$. The substructure, shown in Fig. 11. exhibits characteristics similar to the substructure developed at 482 and $510^{\circ} \mathrm{C}$ at the same nominal stress level. The average cell size is near $0.76 \mu \mathrm{m}$, and perhaps cells walls are more clearly defined than at lower temperatures. The dislocation density is too high to convaniently measure. This substruct ure is consistent with the dislocstion glide, cross slip, and dynamic-recovery deformation mechanism. Carbides are present on the boundaries and are approximately $0.12 \mu \mathrm{m}$ in size.

Other specimens examinid by Bhargava and coworkers ${ }^{26.27}$ include three creep specimens (RP 8 at $276 \mathrm{MPn}$, RP 9 tested at $241 \mathrm{MPa}$, and RP 26 tested at $138 \mathrm{MPa}$ ) and two tensile specimens (RP 14, with an ultimate strength near $385 \mathrm{MPa}$; and RP 201, with an ultimate strength near $362 \mathrm{MPa}$ ). Specimens RP 201, RP 14, and RP 8, which were tested at high stresses, exhibit cell-type substructures, while the specimens at the two lower stresses exhibit what Bhargava et al. ${ }^{26}$ call "mixed" substructures. This is a configuration in which cell walls are more sharply defined than at low temperatures and take on more of a subgrai., character.

25. R. Lagnebotg. "Dislocation Mcchanisms in (reep." Inf. Mefoll. Rev., 11: 1,31 46 11972).

26. R. K. Bhargava, J. Moteff, and R. W. Swindeman, "The Disleration Substruclure. (arbides, and the Deformatliun Map for AISI 304 Stainless Steel," Merdl. Trens., 7 A: 879 84 (1976).

27. T. Ken Field, t/niversity of Cincinnati, 10 R. W. Swindeman, Oak R idge National Laboratory. 1975 


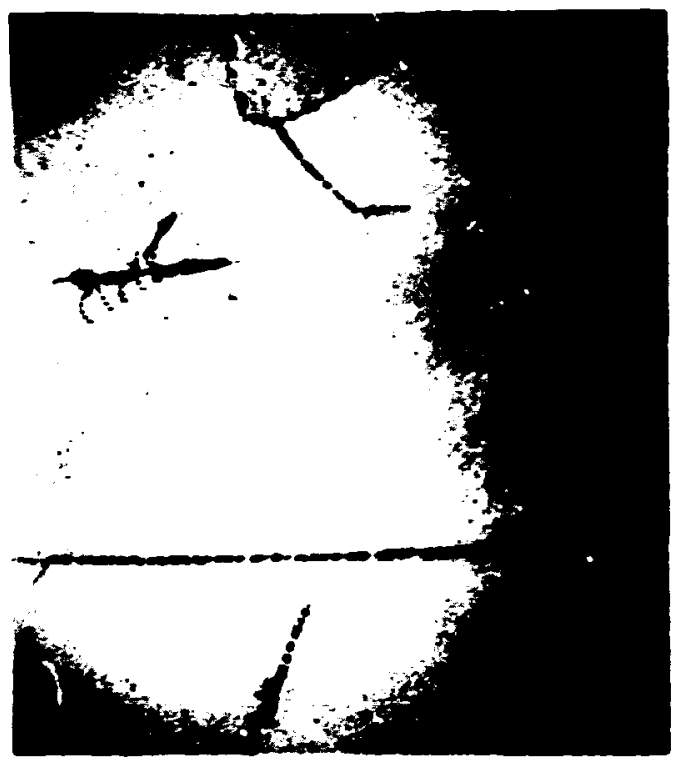

Fie 7. RP 78 resed at $538 \mathrm{C}$ at $41 \mathrm{Mr}$ for

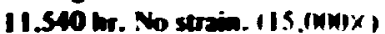

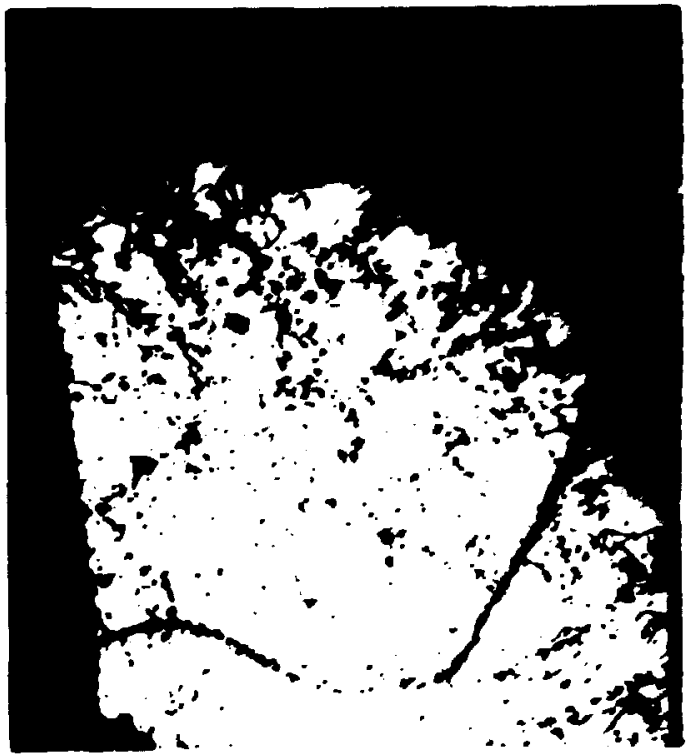

Fiz. 9. RP 78 iesied at 538 ( al 172 MPe for $11540 \mathrm{hr}$. $7.4 \%$ strain. o ncidr $11, .5$. $111^{\circ} \mathrm{cm}^{2}$. (IS.14N)\%
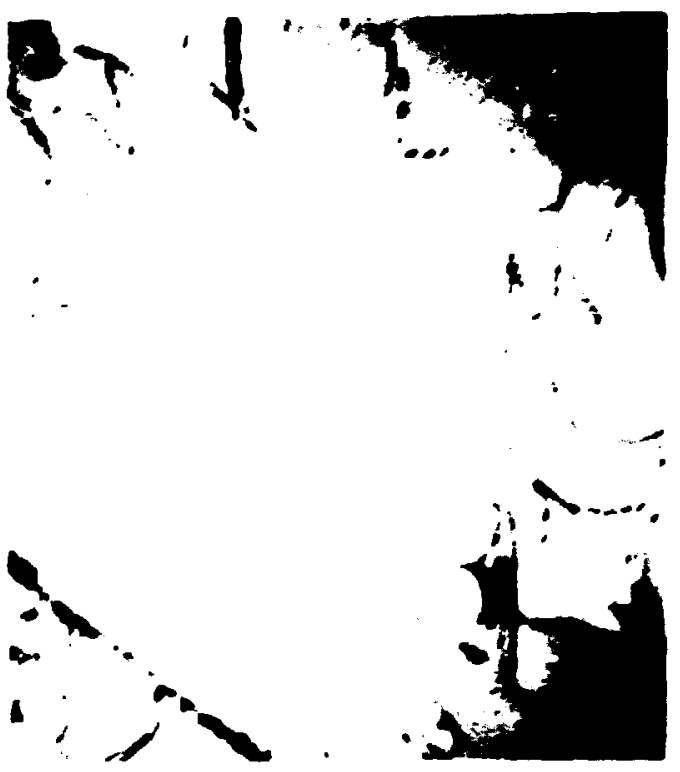

Fig. R. RP 264 rested at 538 C at 86 Whe fox STMD

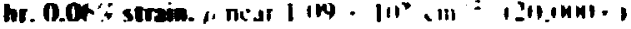

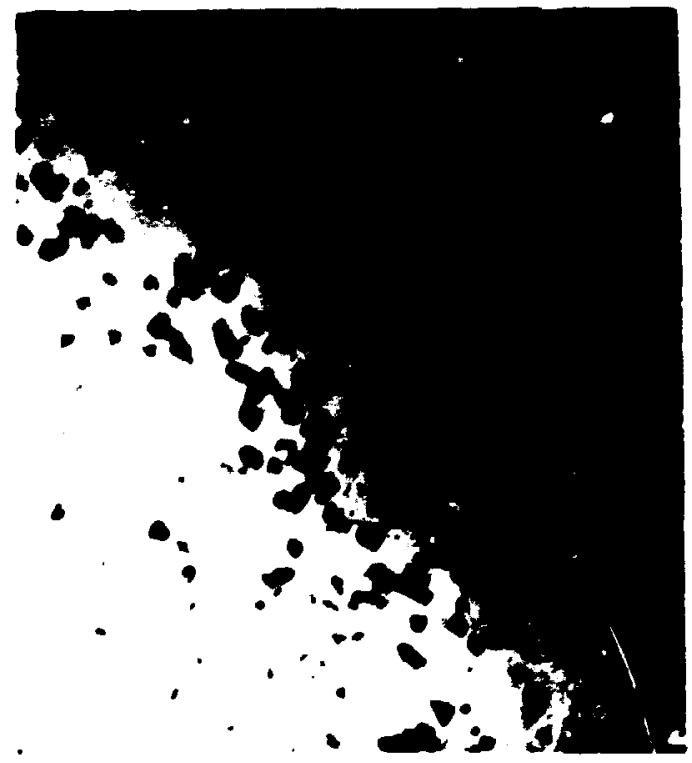

Fig. 10. RP 78 lesied at $538 \mathrm{C}$ at $172 \mathrm{MTe}$ for

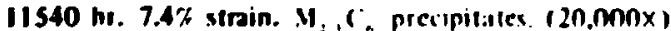




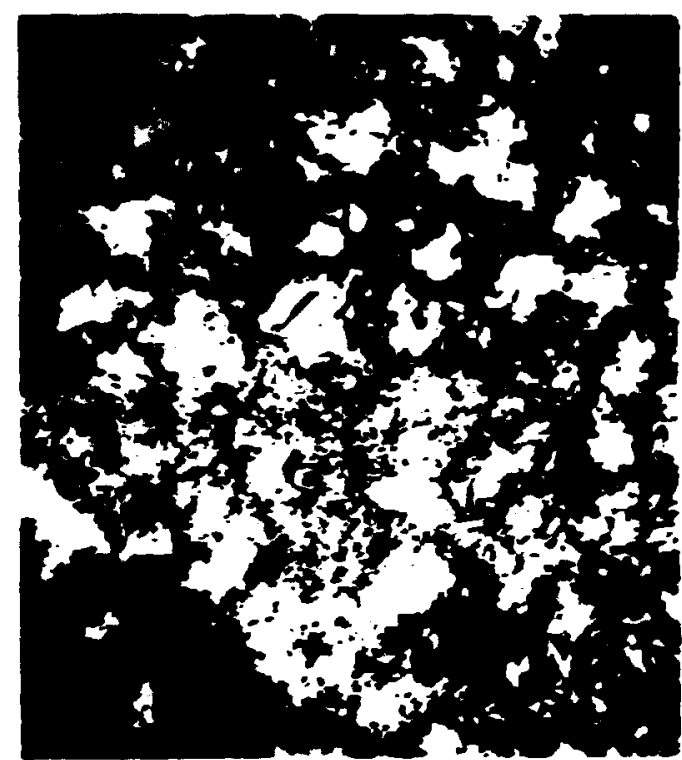

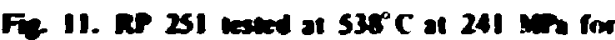

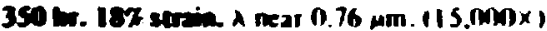

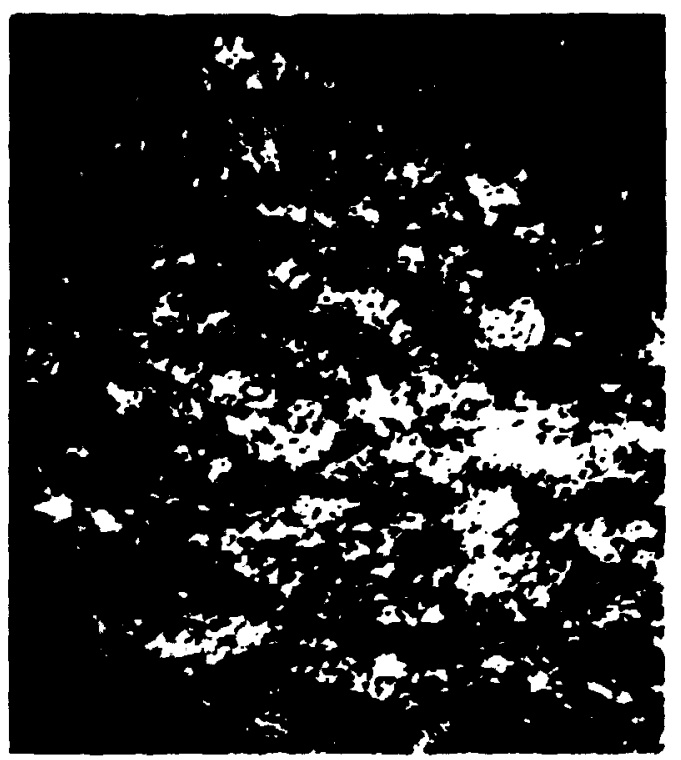

Fie 13. RP 270 ted at $366^{\circ} \mathrm{C}$ at $241 \mathrm{~min}$ for 114 w. 20\% sounin. $\lambda$ near 0.83 min. $(15.000 \times)$

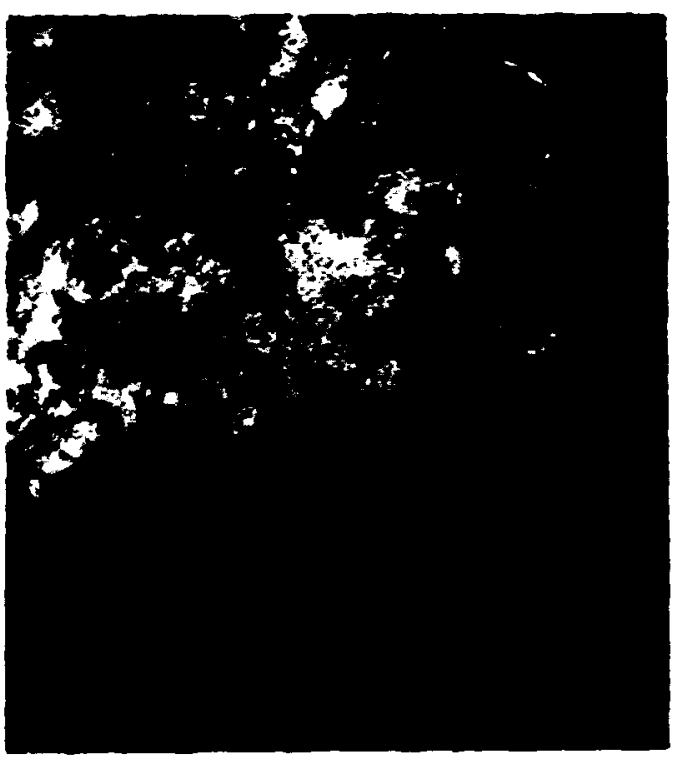

Fic 12. RP 320 teswed at Sef"C at $172 \mathrm{Mre}$ for 2004 hr. $13 \%$ suran.

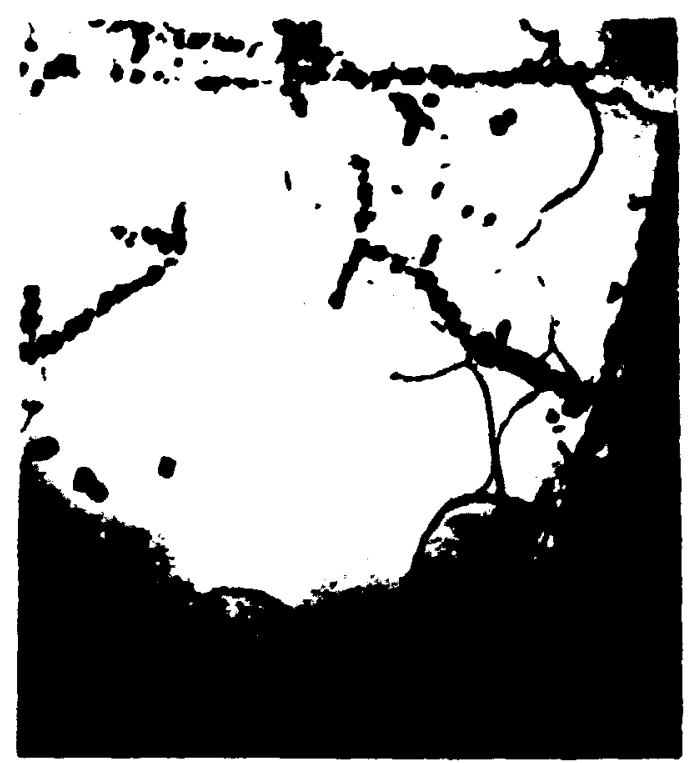

F. 14. AP 215 tested at $593^{\circ} \mathrm{C}$ s. $69 \mathrm{Mr}$ for s00s hr with 0.47\% strain. (20.000) ) 


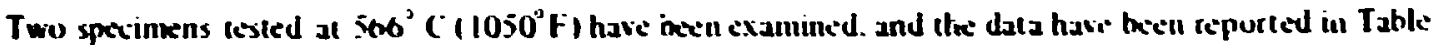
1. The lowstress test specimen (RP 320) at 172 MPa experienced 5 2.F plastic loading stra:. and 7 .8F creep strain betore rupturing after $2054 \mathrm{hr}$. The substructure. shown in Fig. 12. consists of curved dishnidtion tangles which are stabilized by the presence of a dispersion of arbides. There are some repulsive junctions and loops. but all evidence of the planar slip associated with the plastic looding strain is absent. The substructure is similar to that developed : $538^{\circ} \mathrm{C}$ (RP 78). Large carbides are also present on the grair: boundaries. The high-stress test specimen (RP 270) at 241 MPz experienced 10.5\% loading strain and 9.5\% creep strain. Cells are present as shown in Fig. 13. but a rather high distucation density exists within the cells. The structure is apiiti indicative of plide processes. and there is no evidence that thermal recovery plays a significant roke in the deformation: process.

A substantial amount of data are available at $593^{\circ} \mathrm{C}\left(1100^{\circ} \mathrm{F}\right)$. Substructures developed after aging for times up to $10,000 \mathrm{hr}$ have been examined by Sikka et al. ${ }^{23.2 \%}$ u.:0 have determined precipitate sizes on grain boundaries, on iwin boundaries. and within the matrix of this material. With respect to the influence of stress, data determined from studies on eleven specimens are provided in Table 1 . Resulis from a study on an additional six specimens, inciuding two tensile tests. are reported by Bhargava et al. ${ }^{20}$ The lowest stress reported in Table $I$ is near $28 \mathrm{MPa}$. which corresponds to the stress in the shoulder region of specimen RP 213 which ruptured in 15 SCO hr. The microstructure of this specimen, not provided here, is similar to the shoulder region of RP 78. Results from two specimens tested at $69 \mathrm{MPa}$ for $5000 \mathrm{hr}$ are summarized in Table 1. Both specimens RP 28 and RP 215 experienced small plastic loading strains, 0.16 and $0.18 \%$ respectively. and accumulated creep strain less than $0.3 \%$. Subst ructures of the specimens. which are very similar, are shown in Fig. 14. The dislocation densities are near the siarting : Ilue, and no subgrains are present. Dislociation networks with attractive junctions are decinralied with precipitates of a size near $0.08 \mu \mathrm{m}$. Witlun these networks curved dislocations withcul precipitates exist. The deformation mectanism producing this structure could be the thermally aitivated breaking of nodal points on the networks and the subsequent glide and recombination of dislocations within the stabilized nelworks. " Clearly. the carbide precipitate stabilizes the dislocation substructure. but it is questionable whether the precipitates contribute directly 10 creep hardening. All increase in hardness after long-time aging was observed by Sikka et a..."3 however. implying that the precipitatc is hardening with respect to plastic flow.

Very similar substructures are developed after creep tes' ing at stress levels ranging from 46 to $138 \mathrm{MPa}$. The plastic lorading sirains range from 0.88 ; for specimen RP 216 al 86 MPa. to 2.8\% for specimen RP 58 at $138 \mathrm{MPz}$. Creep strains. repurted in Table 1. range from 0.48 $105.8{ }^{\circ} ;$ for speciunens RP 216 to RP 58. respectively. Typical substructures developed in the six specimeils are shown in Figs. 15 through 20. Nejther cells nor subgrains have developed in any of the specimens, but the dislocation density in the specimens discontinued after approximately $5000 \mathrm{hr}$ increases by about 40\% when there is a $60 \%$ increase in stress. Three specimens tested at $121 \mathrm{MPa}$ for different tirmes (creep strain) exhibit nearly the same dislocation density at 1027 and $5131 \mathrm{hr}$. but show a higher value at $15.500 \mathrm{hr}$. Substructures consist of short and curved dislocation segments joined in a network of small langles with many repulsive junctions. A few loops and dipoles are also present. The precipitates often lie on what vere once slip traces or on long straight dislocations. Matrix-carbide sizes are relatively independent of stress, b!ut range with time from $0.035 \mu \mathrm{m}$ at $1027 \mathrm{hr}$ to $0.09 \mu \mathrm{m}$ at $15.500 \mathrm{hr}$. Typical substructures for specimens RP 43 and $\mathrm{Kr} 166$ are shown in Figs. 21 and 22. Figure 21 represents the substructure developed after 619 hr at $172 \mathrm{MPa}$. and Fig. 22 shows substructure development after $98.5 \mathrm{hr}$ at $207 \mathrm{MPa}$. The dislocation densities are grealer than those observed at lower stresses. and the subsiructures are quite variable. Sume foils exhibit intense tangles. perhaps stabilized by the precipitation of fine carbides. while in other areas discernible cells are present. Often the precipitates are aligned on wha: were once slip bands. Because of the shorter times involved. the matrix precipitates tend to be smaller at these high stresses. Substructural features for high-stress tests at

28. V. K. Sikka and C. R. Brinkman. Uniexiel Tensile Properties of Ausienific Stainless Stecls Followine Prion Creep Defometion An Interim Report. ORNI./TM-\$193. ()ak Ruder National I.abufalury (April 1976). 


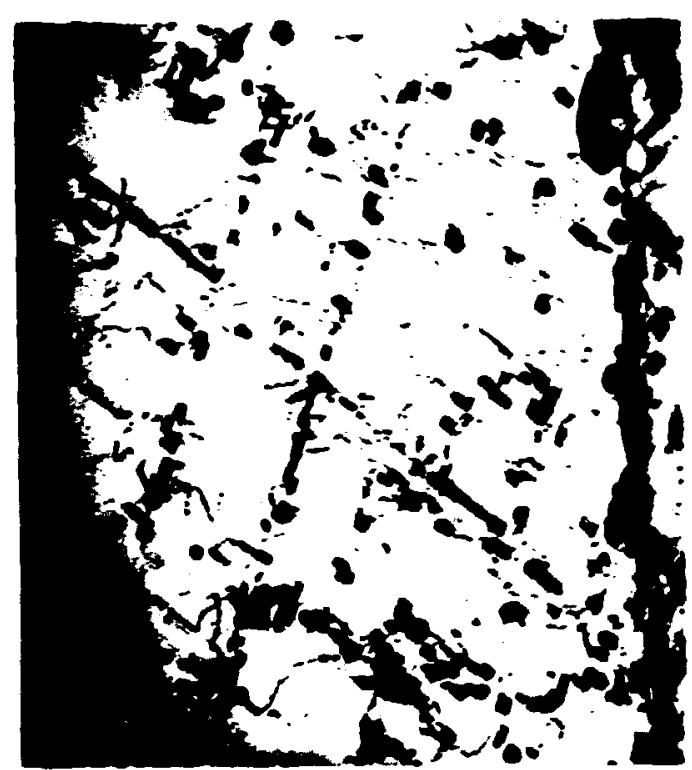

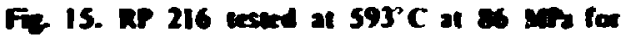
seos in with 1.367 strice o near $3.4 \times 111^{\circ} \mathrm{cm}^{3}$. (20.000)

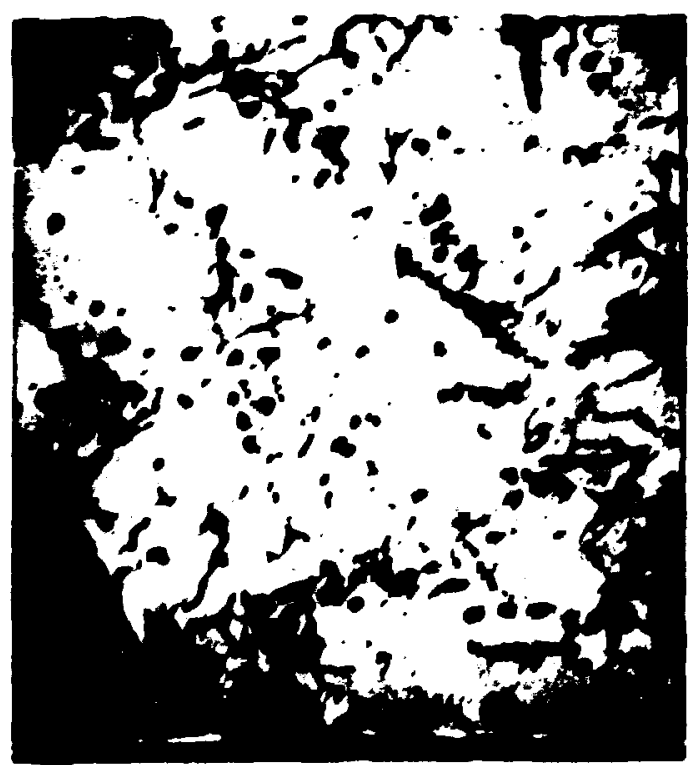

F. 17. RP 133 tasted at $595 \mathrm{C}$ at 121 wre for 1027 hr with $3.15 \%$ st cin. p near $4.88 \times 10^{4} \mathrm{~cm}^{2}$. $(15,000 x)$

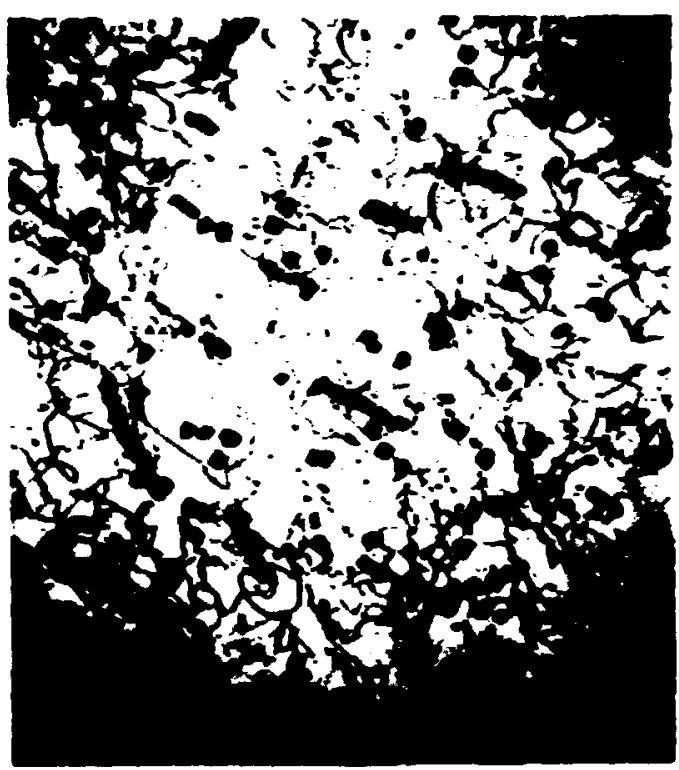

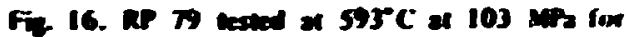
sole in with 2557 strin. o near $4.75 \times 11^{\circ} \mathrm{cm}=$ (15. (100) $) 1$

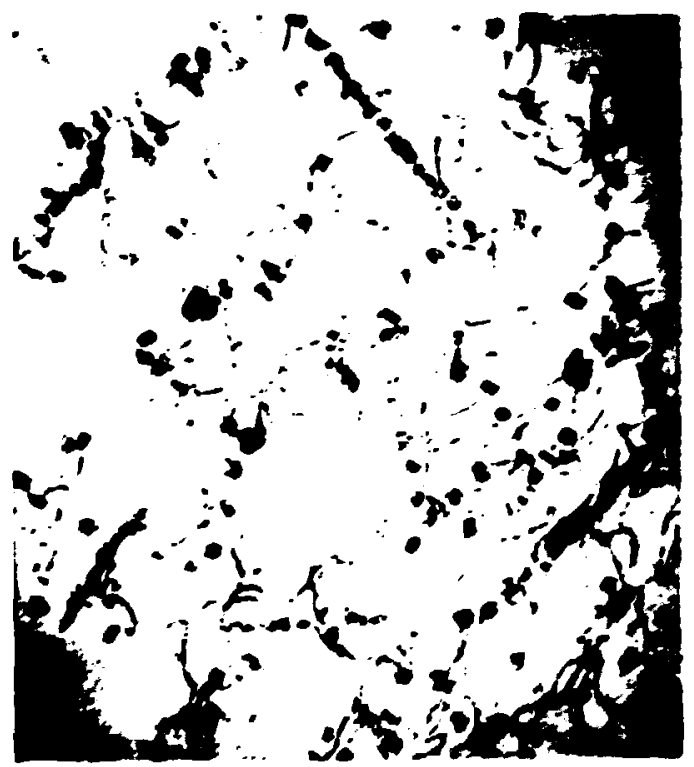

Fa. 18. RP 10 cested at $593^{\circ} \mathrm{C}$ al 121 Mirs for 5131 hr with 5.02 strain. n near $4.6 h \times 110^{\circ} \mathrm{cm}^{2}$. $(20.0 m \times x)$ 


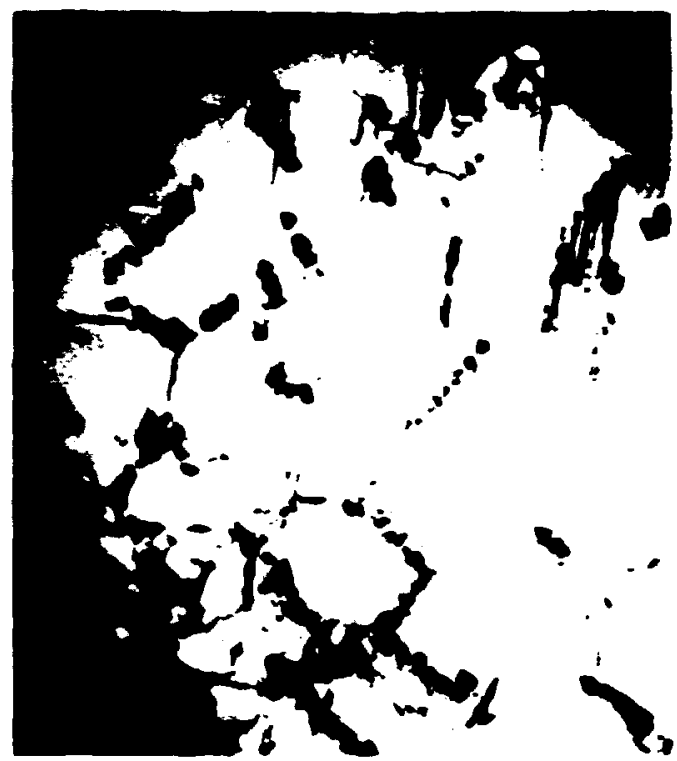

Fie. 19. RP 213 resed al 593 C a 121 wis for 15,500 in with 567 strica o rest 5.63 , $111^{*} \mathrm{im}$ ". (IS.MMIx)

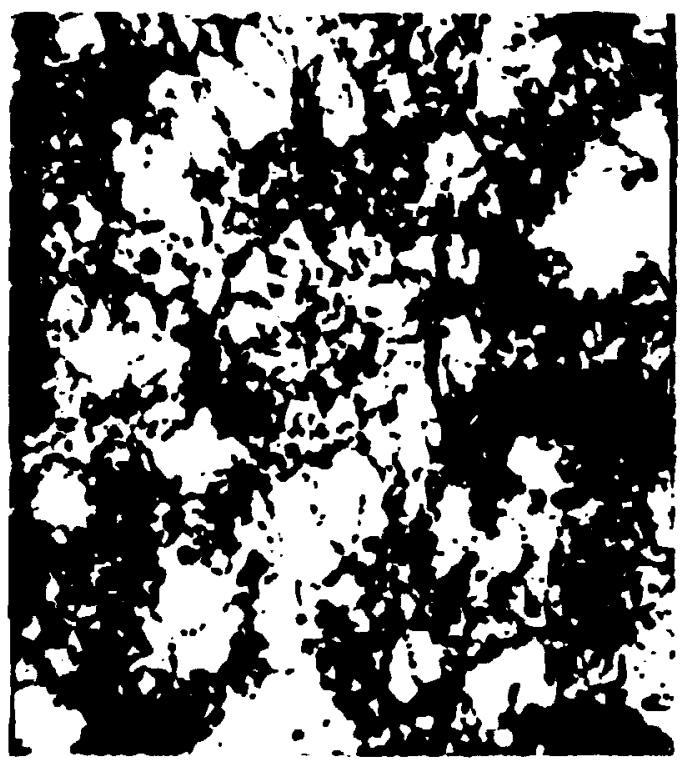

Pit. 21. RP \&3 lested at 593 C ar 172 MPa for 619

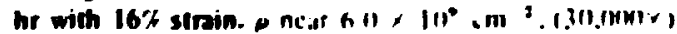

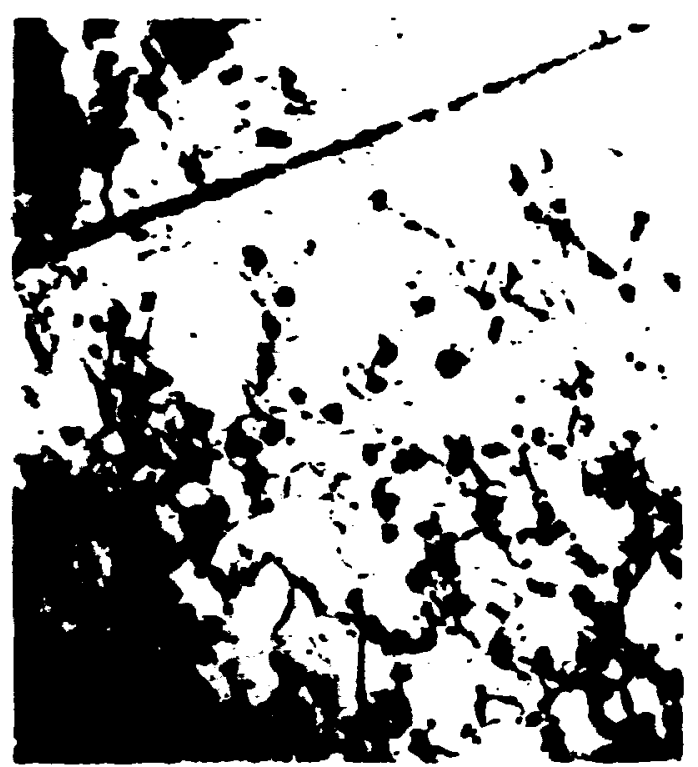

Fie. 20. RP 58 exwed at 593 C at 135 mis tor 5000 in with 8.6\% strien. o mist $+x 2 \times 110^{\circ}$ in $^{2}$. INIIInxix)

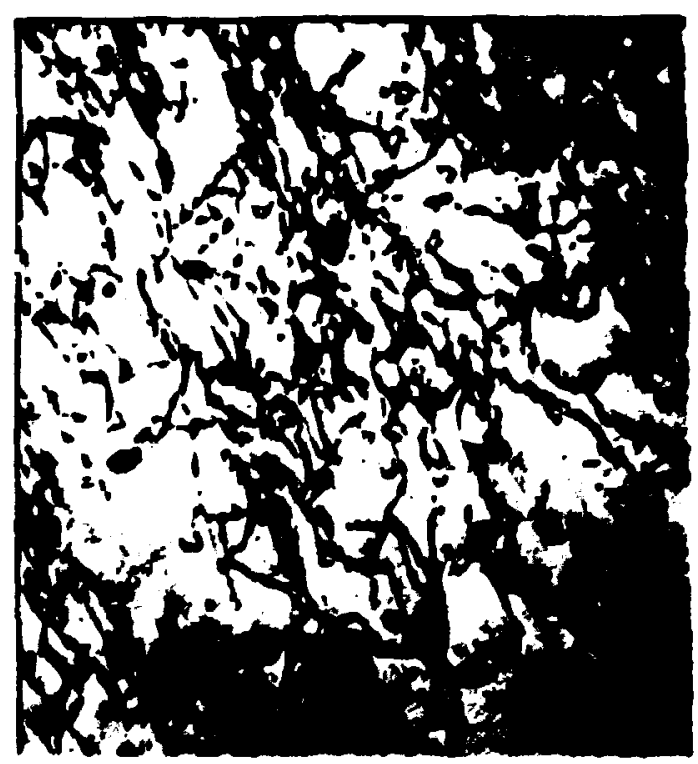

Fig. 22. RP IS6 lested at 593 C at 241 MPa for 98.5 he with $21 \%$ strain. " nest $111.1,11)^{\circ} \mathrm{cm}^{2}$. (J). INm); 
$593^{\circ} \mathrm{C}$ are also summarized by Brargara et al." Dislucations tend to exhibit "mixed" or cellular configurations. The lensike tests exhibit cellular substructures with few, if any, matrix arbides.

Two specimens tested at $621^{\circ} \mathrm{C}$ ( $1150^{\circ} \mathrm{F}$ ) have been examined with the data summarized in Table 1 . The low-stress test specimen (RP 266) nuplured in 4595 hr at 103 MPa. The plastic loading strain is 13\%. and the creep strin is 16.7\% The substructure (Fig. 23) differs markedly from substructures produced by the same siress at lower teniperatures. (See Fig. 15, for example). At $621^{\circ} \mathrm{C}\left(1150^{\circ} \mathrm{F}\right)$. well-delined subgrains develop. Within the subgrains, disloation matworks exist which often exhibit attractive junctions. This type of substructure is typical of high-temperalure deformation where thermal-recovery processes. especially distocation dimb. are very active. The distoation density of $2.64 \times 10^{\circ} \mathrm{cm}^{-2}$ within the grains is low. This substructure is somewhat surprising and may indicate that the temperature controlker malfunctioned and pruduced overheating. This had to happen very quickly, however, because independent monitoring of remperatures occurs on a daily basis, and no temperature excursion was observed. The substructure exhibited by the high-stress test (RP 263) is similar to that observed for the same stress (I 72 MPa) at lower temperatures. This consists of areas where intense tangling develops amid a dispersion of matrix carbides. The typical substructure is represented in Fig. 24.

The substructures developed in specimens tested at $649^{\circ} \mathrm{C}\left(1200^{\circ} \mathrm{F}\right)$ are consistent with data widely available in the literature for austenitic stainless steels. ${ }^{29-32}$ Our study included five specimens tested in the stress range of 35 to 86 MPa for times up to $10,000 \mathrm{hr}$. Supplementary data have been reported by Moteff and coworkers ${ }^{33.26}$ for stresses in the range of 103 to $321 \mathrm{MPa}$. including four tensile tests at different strain rates.

With respect to aging alone, Sikixa et al. ${ }^{20}$ have observed the precipitation of carbides for times up to $10,000 \mathrm{hr}$ and have reported an increase in the hardness. yield strength, and creep rate as a consequence of this precipitation. The substructure is virtually the same under low-stress creep conditions as for aging without stress: a typical substructure (RP 158) for a test at $35 \mathrm{MPz}$ and $10.000 \mathrm{hr}$ is shown in Fig. 25. The specimen experienced no plastic loading strain ard only $0.238 \%$ creep strain. The dislocation density for this specimen and for one tested for $10,000 \mathrm{hr}$ it $51 \mathrm{MPa}$ is essentially the same as for an unstressed specimen. The precipitates are very large, near $0.2 \mu \mathrm{m}$, and are not distributed along dislocations. The precipi--tes usually have a curved dislocation assucialed with them. Both attractive and repulsive junctions are observed in the dislocation network. and in a few instances extended nodes are present. The substructure in the specimen (RP 126) stressed at 51 MPa for 10,000 hr is shown in Fig. 26. It is similar in almost all respects to the substructure developed at 35 MPA (RP 158). At 69 MPa. hoivever. the substruct ure assurnes a new character, as observed in specimen RP 144 which accumulated about 5\% creep strain in reaching the tertiary creep stage around $8000 \mathrm{hr}$. The substructure in Fig. 27 consists of subgrains. with precipitates sometimes decorating the walls. The dislocation network within the subgrains has segments which are sometimes straight and sometimes curved; a fairly high density of altractive junctions is present. The larg matrix carbides usually have dislucations associated with them. The substructure suggests that the deformation is dominated by thermal-recovery processes, such as dislocation climb.

Two specimens, RP 87 and RP 247, were tested at $86 \mathrm{MPa}$. Both specimens experienced about the same plastic loading strain, but the creep strain for specimen RP 247, which was discontinued slightly into the tertiary creep stage, is abnut half that of RP 87, which was tested to failure. The substructures for the specimens are aimilar and consist of well defined subgrains containing dislocation notworks. The substructure shown in Fig. 28 is typical. The network segments vary in character and are sometimes curved

29. F. Garofalo et al., "Strain-Time. Rate-Stress, and Rate-Temperalure Relalions during Latge Deformations in Creep," pp. I-31 in Jalme Imt. Conf. Creep. Inst. Mech. Fine. London, 1963.

30. L. 1. Coddy. "Intermal Siresces and SIructurss Developed During Creep." Metall. Trens., 1: 395 401 (1970).

31. S. N. Monteiro and H. J. Kestenbach, "Influence of Grain Orientation on the Disucution Substructure in Austenitic Stainiess Stevl," Metell. Thms., 6A: 938 - 40 (1975).

32. T. L. da Silveira and S. N. Montelio. "Strenptiened Creep Subsinuctures in 316 Stainiess Stecl." pp. 33498 in 2nd Int. Conf. Mech. Behovior of Merds, American Society of Metals, 1976. 


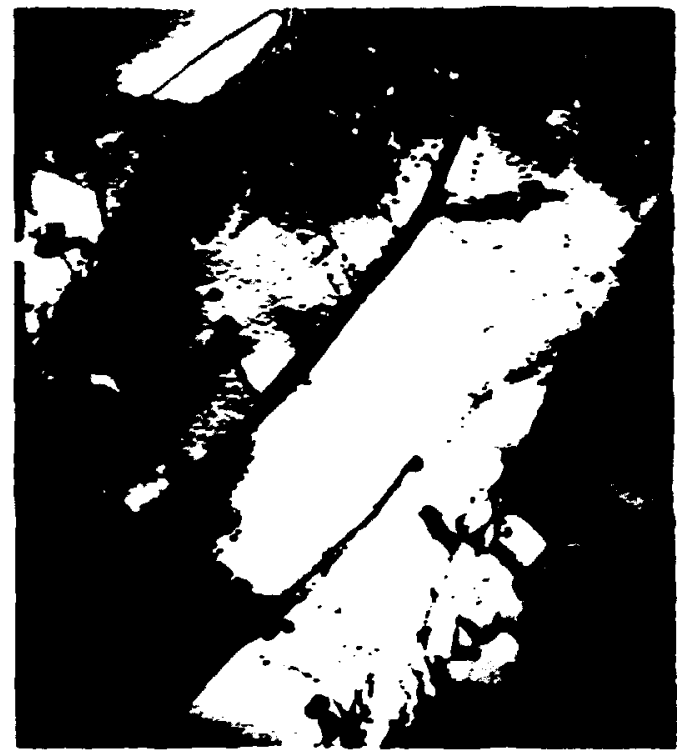

Fiz 23. RP 266 rested at 621 'C at 103 aire for 4595 hr with $18 x$ sturia. $p$ mar $2.64 \times 10^{\circ} \mathrm{cm}{ }^{2}$. A

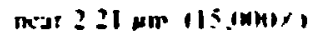

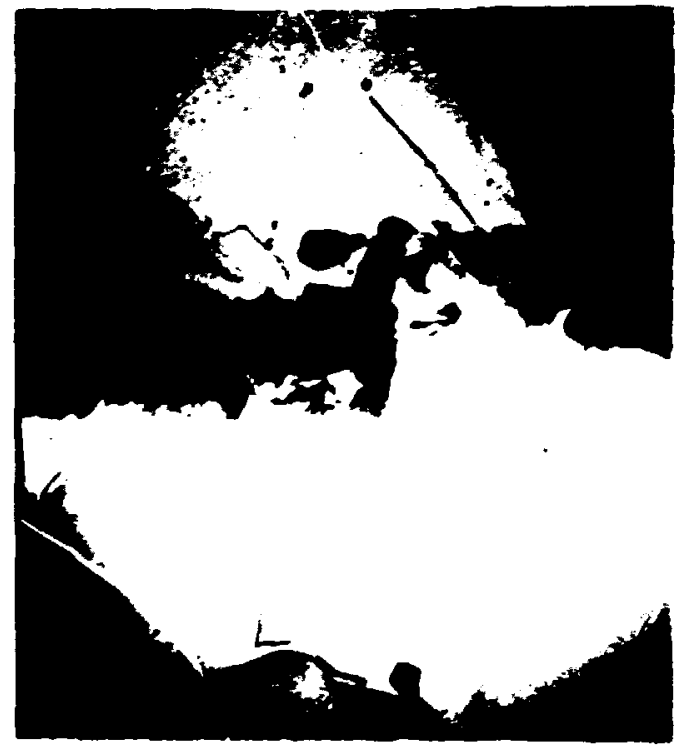

F5. 25. RP 1.is tested at $649^{\circ} \mathrm{C}$ at $35 \mathrm{MPs}$ for $10.000 \mathrm{hr}$ with 0.2 .87 creep strain. p near $11.89 \times 10^{\circ}$ in: (15.(WM)

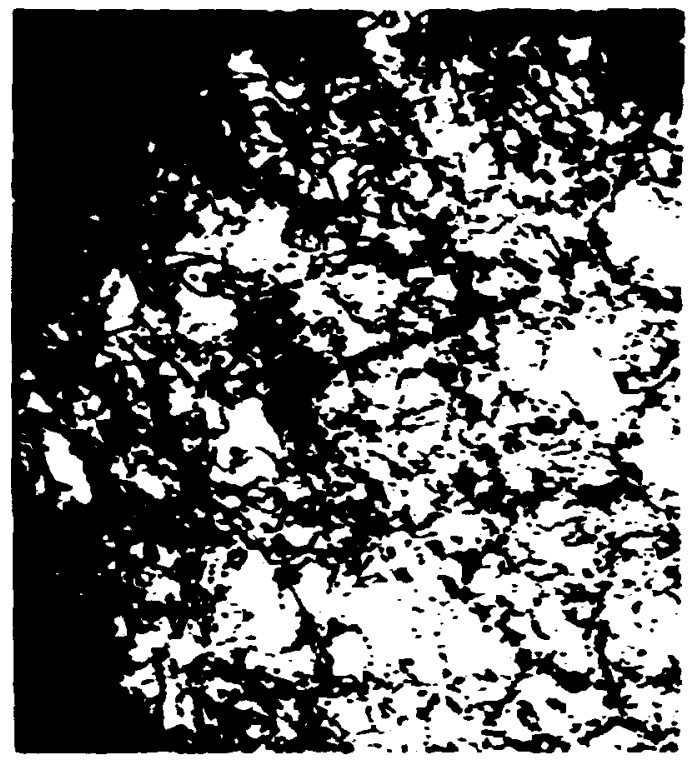

Fiz 24. RP 203 weed at 621 'C at 172 Mre for 119 or with $22 \pi$ stroim. o mear $12.5 \times 111^{\circ} \mathrm{cm}$ " (2019Mm)।

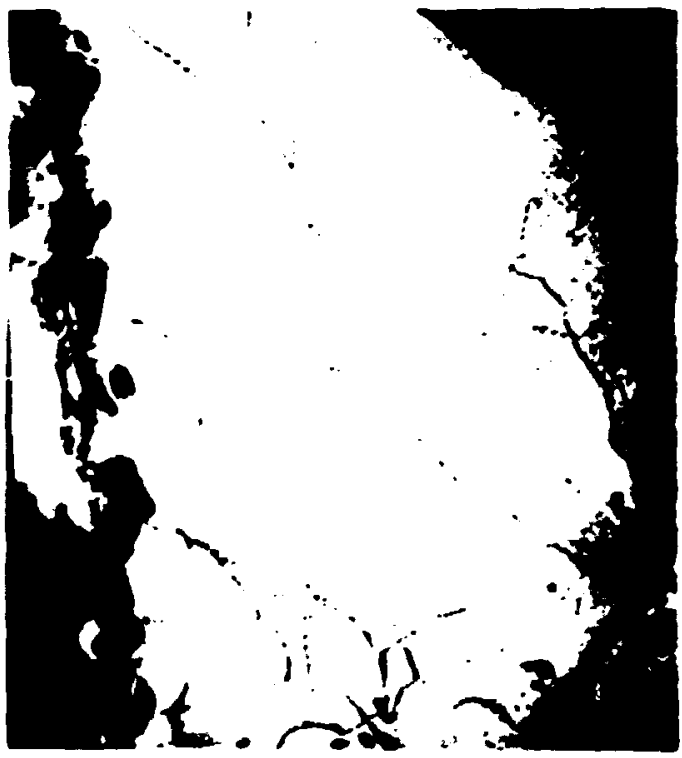

Fiz 26. RP I26 rested at 649'C at 51 Mire for $10.000 \mathrm{hr}$ with $0.66 \%$ creep strain. o near $0.8 .3 \times 11^{\circ}$ $\mathrm{cm}^{2} \cdot 115 . \mathrm{mm} \times 1$ 


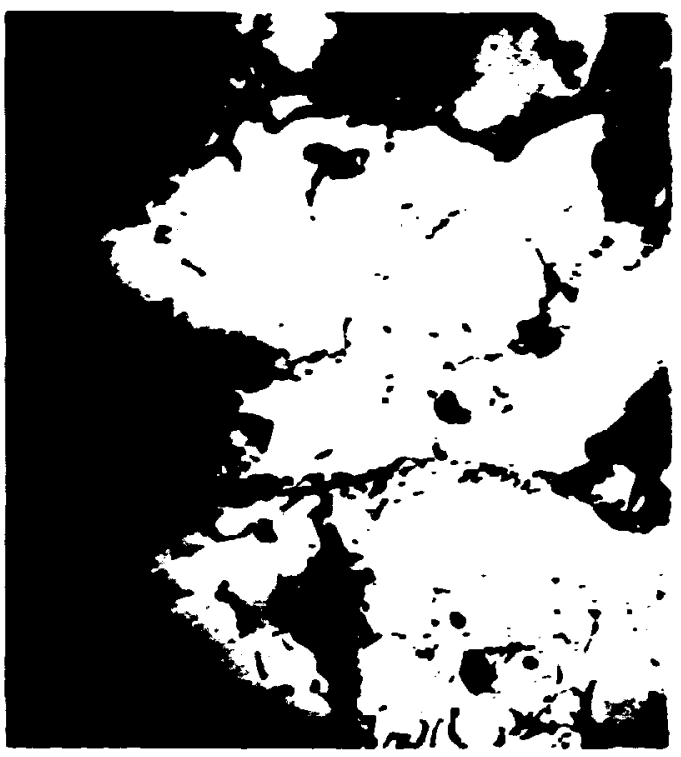

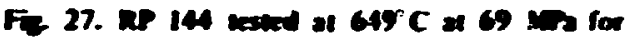

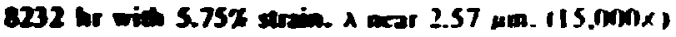

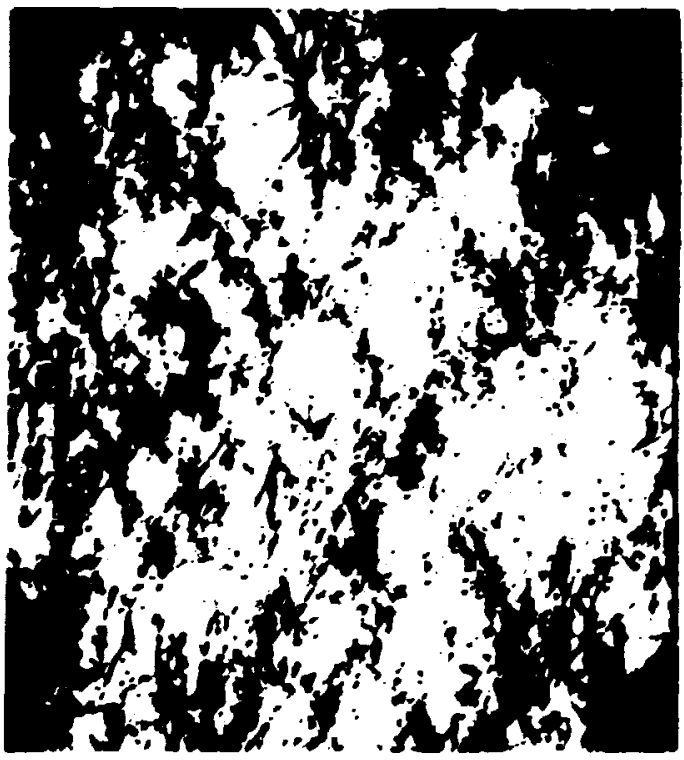

F. 29. FRP 107 resud af $42 T^{\circ} \mathrm{C}$ at $0.37 \%$ af $\mathrm{for}$ 1000 cycles at 148 mes. o near $7.66 \times 10^{\circ} \mathrm{cm}^{-2} . \lambda$ near $1.46 \mu \mathrm{m}(10,000 \mathrm{x})$

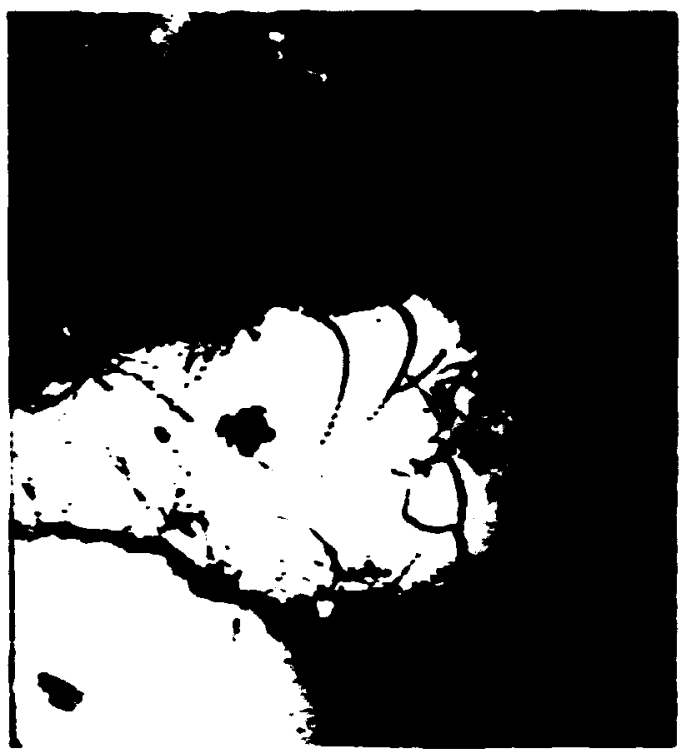

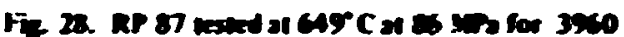

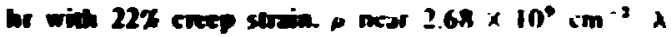
neat $1.99 \mathrm{~mm} .1260 .9 \mathrm{~mm} \times$

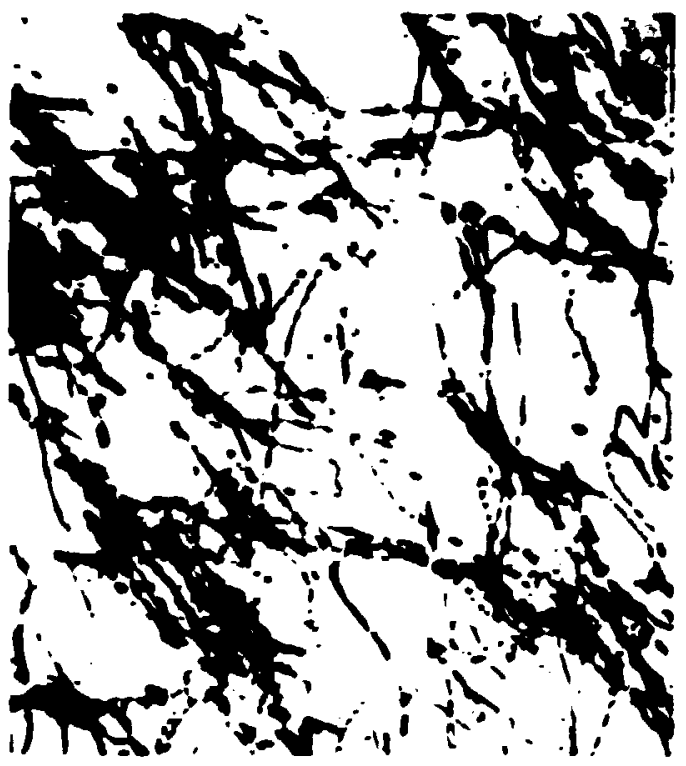

Fin. 30. FRe 107 lested at 42 r $a 10.377$ se for 1000 cycles at 148 MPs. (3n, $\mathrm{mm}) \times$ ) 
and sometimes straight as when tested at $69 \mathrm{MP}$. Both attraitive and repulsive junctiuns ase present. and extended diskotion nudes are vaxionally observed. Large blocky matrix arbides are present and are usually surrounded by dislocation tangles. Substruitures developed in ireep and tensile tests at stresses of 103 and 138 MPs cunsist of subgrains. with walk sometimes decorated by precipitates. Dishoctions within the subgrains are often suraght with attractive jumitions. Matrix precipitates form rows. susfesting that they developed on tip treces produced during loating. The substructures indicate that the creep deformation at $69^{\circ} \mathrm{C}\left(1300^{\circ} \mathrm{F}\right)$ is controlled by thermal-recuvery provesses. such as dislocation ilimb. As stresves are increased, however. subgrains give way to velt. and the ma.,ix precipitates beciome smalker as testing times hecome shorter. Additional data pertaining to the development of substruitures under ireep and tensile conditions are available elsewhere ${ }^{24.2 *}$ for temperatures of 704.760 . and $816^{\circ} \mathrm{C}$. Dependins un the sirtss. either subprains or cells are formed and precipitates. when they develop. ar: charaiteristinally very lark.

Just 25 microstructural data are needed for the carly stages of creep at temperalures and stresses of concern to the LMFBR program. so also are micrmstustural data needed winich pertain to the carly stages cf cyclic hardening at similar ten:peratures. The sudies here represent a preliminary scupan: Data from six cyclik specimens are summarined in Table 2. which pruvides cell or subgrain incercept values. disloration

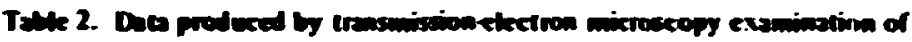

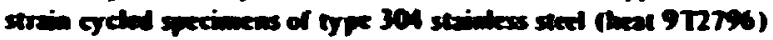

\begin{tabular}{|c|c|c|c|c|c|c|c|c|}
\hline $\begin{array}{l}\text { Specionen } \\
\text { numbet }\end{array}$ & $\begin{array}{c}\text { Tempresature } \\
\text { I'(C) }\end{array}$ & $\begin{array}{l}\text { Cyctix } \\
\text { urain } \\
\text { range }\end{array}$ & $\begin{array}{l}\text { Fofincetinf } \\
\text { stress } \\
\text { amplitude } \\
\text { (MP) }\end{array}$ & $\begin{array}{l}\text { Momilules- } \\
\text { compensoted } \\
\text { true stresse } \\
\left(10^{-3}\right)\end{array}$ & ciscks & $\begin{array}{c}\text { (edi } \\
\text { ure } \\
\text { (mon) }\end{array}$ & 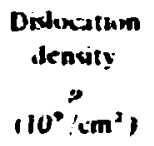 & $\begin{array}{l}\text { Cirain } \\
\text { bisundaty } \\
\text { carbide } \\
\text { (mon) }\end{array}$ \\
\hline FRP 107 & 427 & 0.37 & 148 & 5:5 & (1) & $1.46 \div 0.32$ & $7.66=1.76$ & $\mathrm{NO}^{\circ}$ \\
\hline IRP IIN & 482 & 0.37 & 154 & 2.35 & InWwie & $1.23: 0.21$ & $5.34=1.26$ & NO \\
\hline FRP IIS & S3A & 0.37 & 17! & 2.84 & $<2(x)$ & $1.13=0.30$ & & $\mathbf{N M}$ \\
\hline IRP IIO & 649 & n. 375 & J32 & 2.34 & 100, & $2.24=0.32$ & $1.3=1.0 n$ & $\mathbf{N M}$ \\
\hline IRP 1109 & 649 & 11.62 & 150 & 2.65 & ION) & $1.6 \pi=0.15$ & $7.10 n=1 . \$ 11$ & NO \\
\hline IRP 111 & $6+9$ & 0.149 & $|6|$ & $2 \times 5$ & Itn) & {$[.6]=0.10$} & $6.55=1.62$ & NO \\
\hline
\end{tabular}

Siran rate mear $\$ .3 \times 10)^{-3} / \mathrm{xec}$.

Sires value close lo the oturathm condithm.

CAxial stress amplitude/shear modulus.

ANO = mot ohserved. NM = observed but nut neasured.

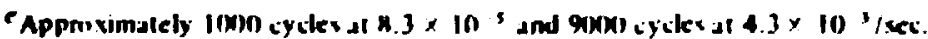

densities and carbide-precipitation behaviur. Für specimens (FRP I07. FRP I06. FRP II5. and FRP II0) were cycled at a tutal strain range near $0.37 \%$ at 427.482 .538 . and $644^{\circ} \mathrm{C}$. respectively. Two specimens. FRP 109 and FRP III, were cycled at higher strain levels at $649^{\circ} \mathrm{C}$. Tesl times at the 0.37 r strain range wete similat. although one test specimen (FRP 106 ) was carried $1010^{*}$ cycles by increasing the test frepuency after $10^{\prime}$ cycles. Transmission eleciron micrographs for the specimen tested at $4: 7^{\circ} \mathrm{C}$ are shown in Figs. 29 and 30. The substructure consists of tangles of dislocations occurring at the intersection of slip Iraces (Fig. 29). The high-magnification micrograph (i.ig. 30) reveals the presence of loops. dipoles. and multipoles. These features are typical of the carly stages of cyclic hardening observed by Nahm ef al. 3 Although a well-defined cell siructure has not develuped. there is sufficient delineation in permit an estimale of the cell-size limit $A$ ). which is near $1.46 \mu \mathrm{m}$. Misurientation occurs between the cells in some cases and a typical angle is near 0.1 degice. The disloration density. $\rho$. is near $7.7 \times 10^{\circ} \mathrm{cm}^{-1}$, and no vidence of a precipitate exisl in either the grain houndaries or in the matrix. The substructure developed

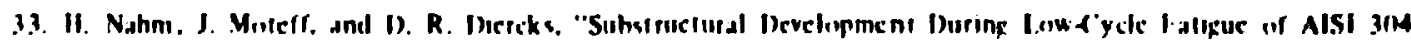

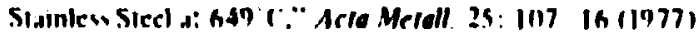


at $482^{\circ} \mathrm{C}$ (FRP 106) and shown in Fip. 31 is similar to that deweioped at $427^{\circ} \mathrm{C}$. Nthough the cyclic-stress range is virtually the same, both the cell size and the dustocation density are smalke in the $482^{\circ} \mathrm{C}$ tested specimen. It is not cleat whether this discrepency neflects the differences in the temperature or the total accumubied plassic strain. Nko. it is possible that more foils need to be examined.

Tests conducted at $538^{\circ} \mathrm{C}$ (FRP IIS) show that the cyclic-stress range is substantially greater than at 427 and $482^{\circ} \mathrm{C}$. The substructure shows regions where cell walts are well-defined, as illustrsted in Fig. 32. Orher areas are similar in substructure to the lomer temperatures as illustrated in Fig. 33. Loops, dipoles. and multipoles are present. The cells are only stightly smaller than cells at $482^{\circ} \mathrm{C}$. in spite of the higher cyclic stress. but the range of cell sizes at a single cemperature is large retative to the differences in the averaes at the vrious temperatures. The substructure is consistent with the observatiun of Muleff and coworkers3-35 that the celts tend to develop neas the grain boundaries first and then move inward. Figure 32 reveats the presence of grain boundary carbides aboul $0.1 \mu \mathrm{m}$ in size.

The specionen (FRP 110) cycled at $644^{\circ} \mathrm{C}$ and at the $0.375 \%$ strain range exhibits a lower saturation stress range than at lower lemperatures. On a modulus-compessated irve stress basis, howerct. the stress range is about the same as the range at temperatures of 427 and $482^{\circ} \mathrm{C}$. The cell size is greater, and the distocation density is lower in the specimen cycled at $649^{\circ} \mathrm{C}$. Typical substructures are shown in Fi-3. 34 and 35. These reveal that the cellular structure is in a primitive stage of development in spite of the fact that the specimen was cycled well into the saturation-stress range. The substructure consists of $L$ endkes and tangles, with dipoles and multipoles. Loops are present, some of which are very small and coukd ever. be matrix carbides. Occasionally extended nodes are encountered. The grain boundaries contain precipitates as would be expected from the test duration.

Specimens cycled at higher strain levels at $649^{\circ} \mathrm{C}$ exhibit some regions similat to thuse observed in the low strain tests. Typial regions of this type are illustrated in Fig. 36 for the specimen cycled at $0.62 \%$

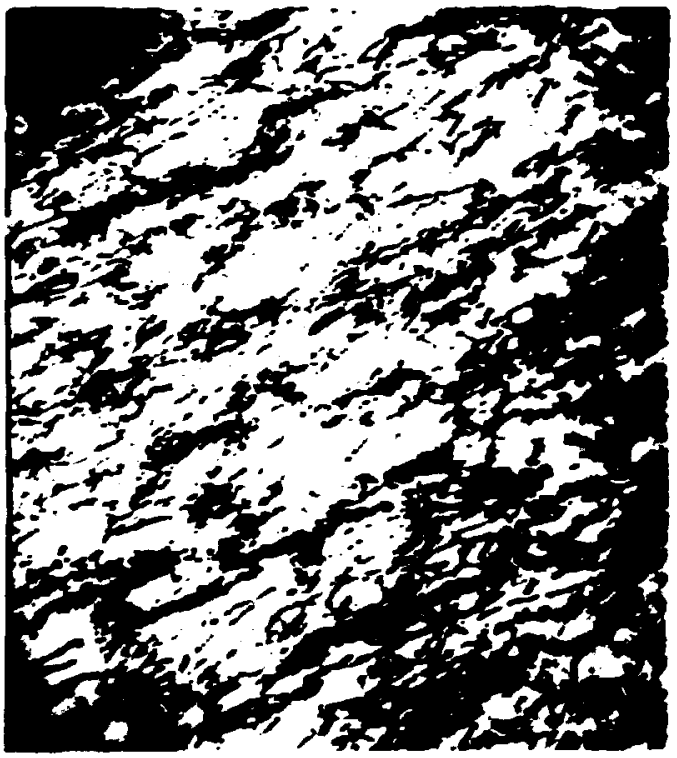

Fiz 31. FIP 105 and at $482 \mathrm{C}$ at $0.37 \%$ ar for $10,000 \mathrm{grales}$ at $152 \mathrm{kin}$ o near $5.39 \times 10^{\circ} \mathrm{cm}^{-2}$. A near $1.23 \mathrm{~mm}$. $(10.000 \mathrm{X})$

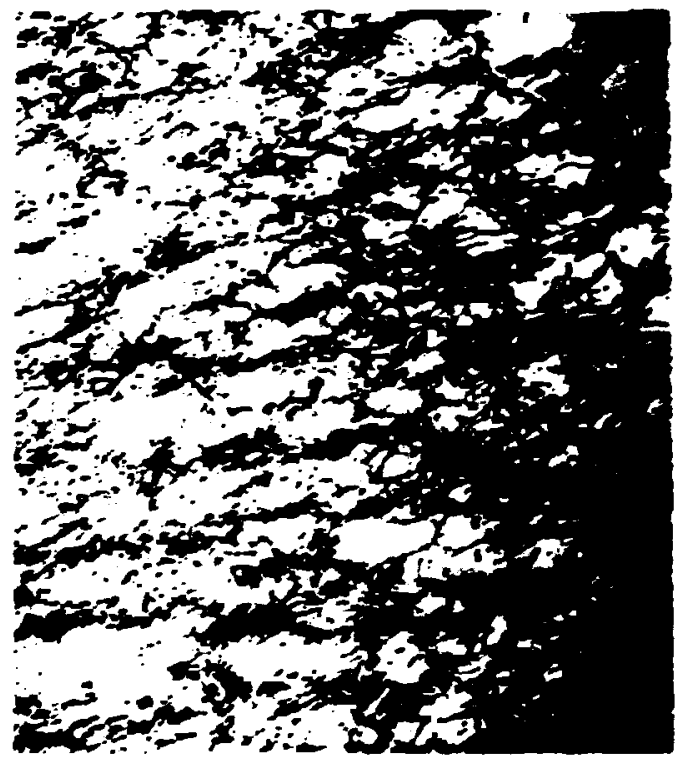

Fic. 32. FRP IIs leated at $538 \mathrm{C}$ at $0.37 \%$ ae for 2000 cycles at : $172 \mathrm{MPa}$. A near $1.13 \mathrm{~mm}$. $110 .(\mathrm{Mm})$

34. K. D. Chalkenper and J. Moterr. "Characterization of the Deformation Suhsinuclure or A ISI 316 Stainless Stecl After High Strain Fatigue at Flevatal Temperatures." Mefall. Thus. 3: 1675 $7 \pi$ (1972).

35. K. D. Chalkenger and J. Moteff. "Correlalion of Substruclure wilh Filevated Temperalure low fycle liatigne of AISI 304 and 316 Stainkss Steel," Fantave at Birvoted Tempentures. STP 520 . American Siciely for Testing Walefials. Thilodelphis, $69-78$ (1973). 


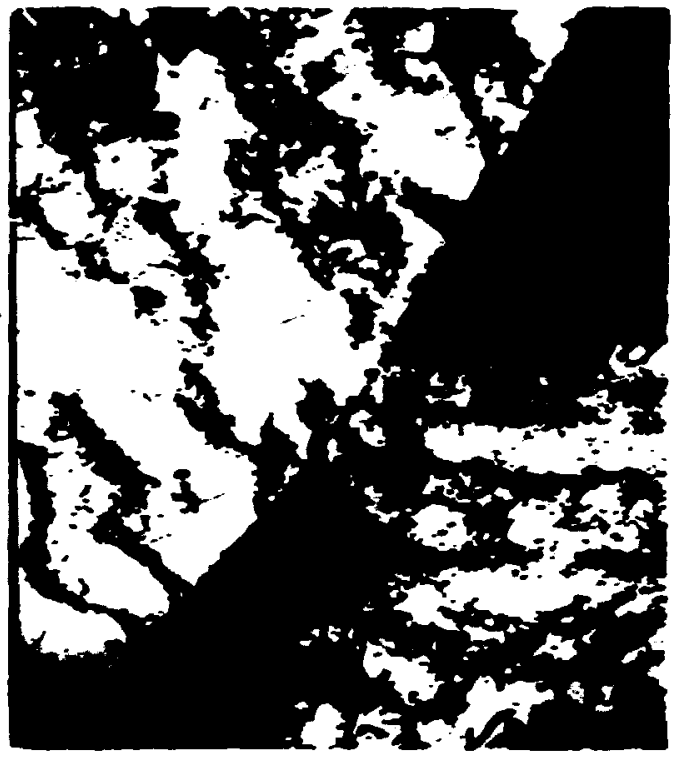

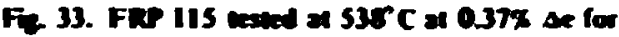
200 cycles $x \cdot 172$ and. $(7 \sin x)$

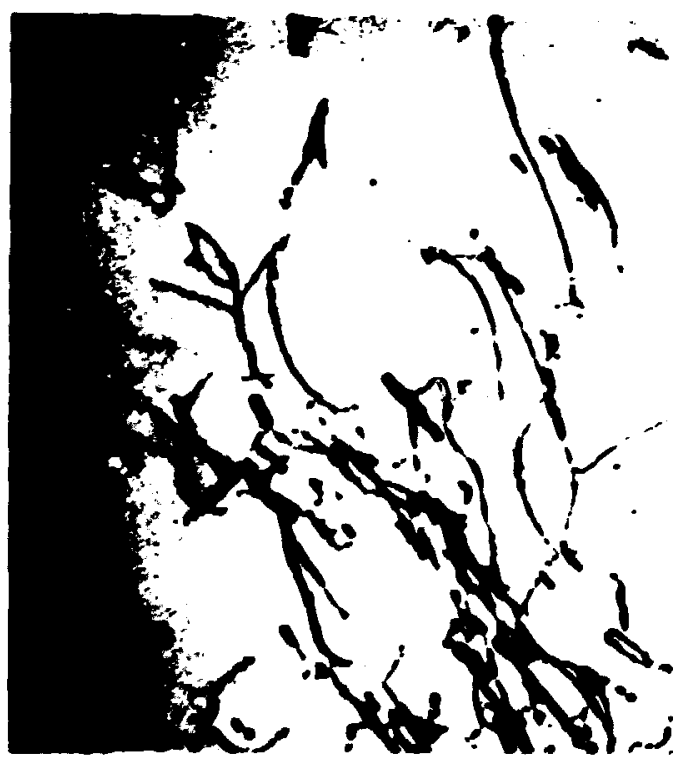

Fis 35. FRo 110 resied a $649 \mathrm{C}$ at 0.3757 ie for 1000 cycles at $\cdot 132 \mathrm{M} / \mathrm{ro} .121 \mathrm{0 \textrm {Mm } \times}$,

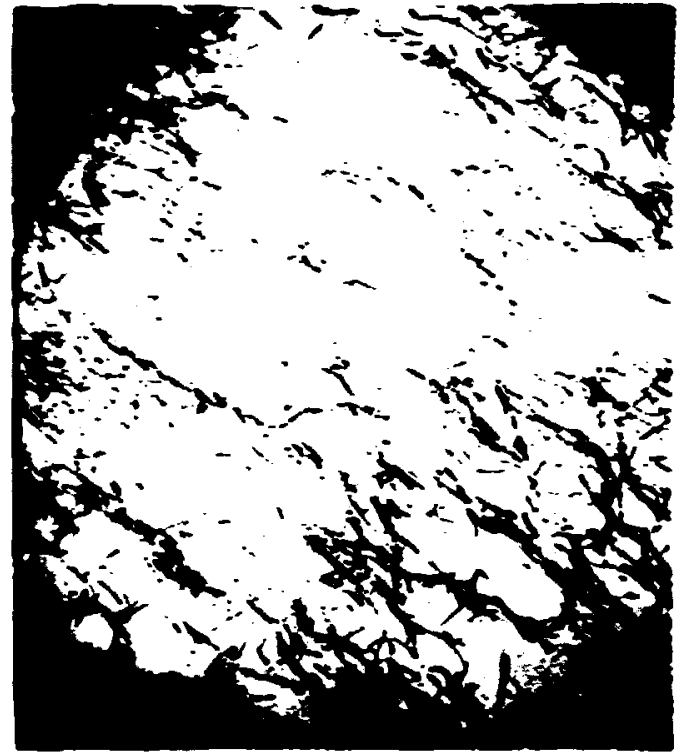

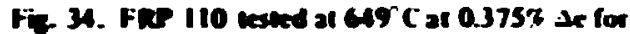

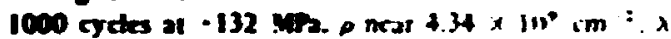
mer $2.24 \mathrm{~mm} .175(\mathrm{~m}) \times)$

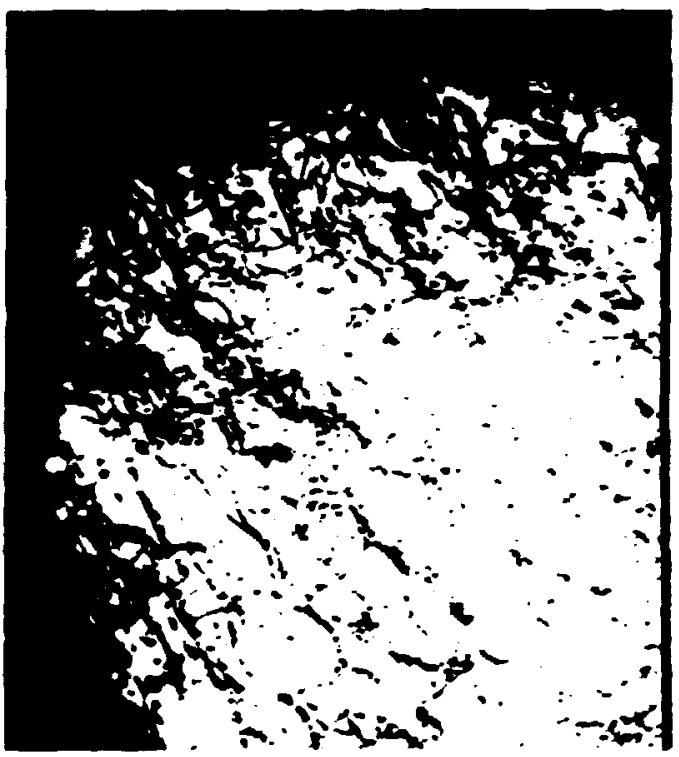

Fiz. 34. FRP 109 resued at $649 \mathrm{C}$ at $0.62 \%$ se $\mathrm{fm}$ 100 cycles at 150 . WP. p near $7.108 \times 111^{\circ} \mathrm{cm}^{2}$. $\lambda$ neat $1.68 \mathrm{~mm} .115 .1 \mathrm{~m}(1)$ ) 


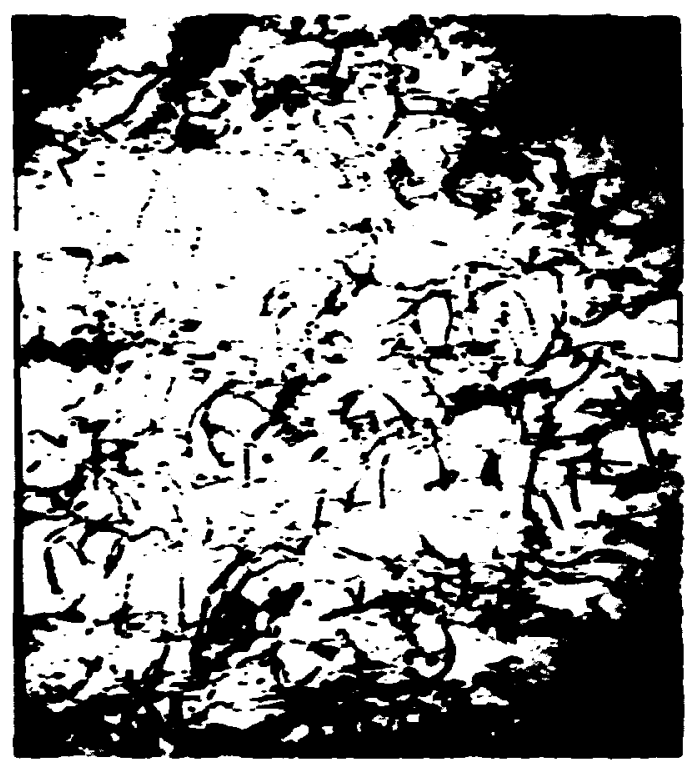

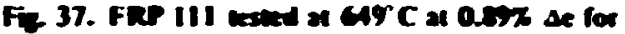
109 creles $x=161$ une neat $6.55 \times 10^{\circ} \mathrm{cm}^{-8}$. A mear $(.63 \mathrm{~mm}$. ( (n.000x)

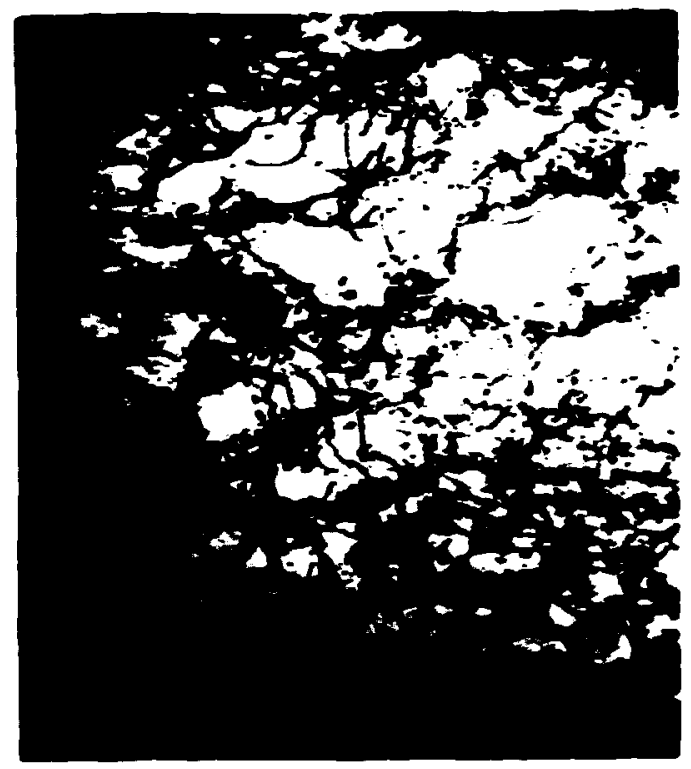

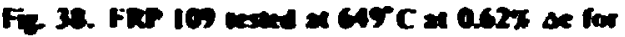

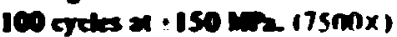

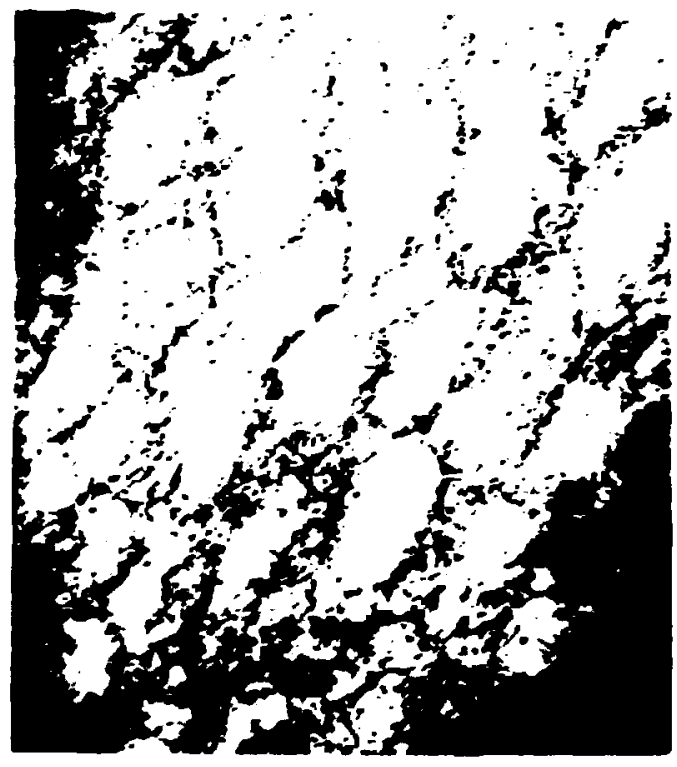

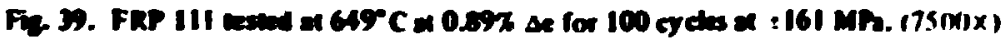

strain range, and in Fig. 37 for the specimen cycled at $0.89 \%$ strain range. Both figures reweal the presence of tangles, dipoles, and loops arranged in a configuration of primitive cells. The subcell sizes and dislocation densities are similar to those observed at lower temperatures and similar stress ranges. Some regions in the specimens cycled at $649^{\circ} \mathrm{C}$ exhibit well-defined cell walls such as those shown in Figs. 38 and 39 for 0.62 and $0.89 \%$ strain ranges, respectively. An interesting feature is that some cells contain curved dislocations which reach almost from one wall to another: these could be gliding dislocations which have broken free of one call wall and are moving towned another. Howevir. the substructure and deformation mechanisms 


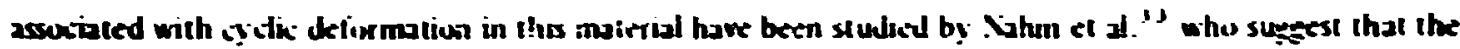

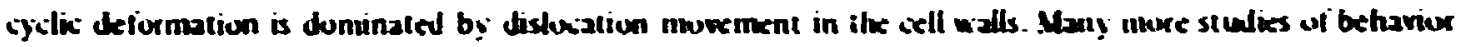
in inc early hordening stogrs are necessory beture ang of seweral cunceivable hardening mudels" "s fiu cyclic behaviur can be ideire: : 1.

\section{DESCUSSOON AND ANAL.YSES}

In describing the substructures deretuped by rarinus combinations of temperature. stress. and sirain rate. we have mentioned sume pussible deformation mechanisas which are cinnsistent with the substructural observations. We have nut been very specilik. howewe. and div not feel that our innowikdge has progressed to a stage where the opperatioc deformation mectanisms can be cinfidently idtentitied and u d to develop constitutive equations. One of the problems is that the majurity of the defornaztion mechanisms, such as those used by Ashby" to to develop defurmation maps. apply to "steadystate" conditions. This is an unlikely event in a strumitural component of an LMFBR. which underguves numervus Iransients during its serviue life. These transients are what introduce the plastic stratns and residual stresses which retax by creep. Weally. the developer of constitutive eqwitions shoubl understand mechanistically. Ite mature of plasticity and creep deformations and how they interact. An iminoriant suestien relative io the current constitutive relations is whether or not separation if ereep and plasikity is really essentiai. If not. we must decide whether it is proper lu separate the plasticity and ereep simply ior compulational convenience. The substruiture sudy presented here does not provide tinal answers in thire: problerils. hut when combined with the existing knowkedge of mechaniel behuvior. It diks represent a step in ilk nọht dinecition igward reaching a proper selution.

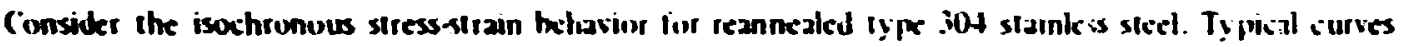
are shown in Fig. 40 at initial loading loctul tim and atter $5000 \mathrm{hr}$. This material has a vert ! iu clastic

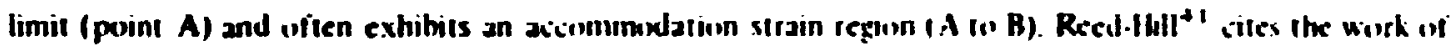
Zankl.42 who describes large grains favorahly orientaled for slip which tunderg̣o plastis gielding hetorte general yielding. Disloxitions on ailive slip planes within the "weah" grains umpinge on grain briundaries and trigger accommudation slip in neighboring grains. Vield-surlacie slodies en:ployed in develop hardening

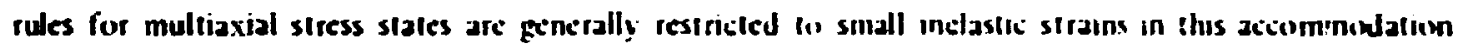
range. aboul $10 \times 10^{-h}$ in so $\times 10^{-6}$ ofitsel sirain." In relation in the sieep slieng̣th. the stresses

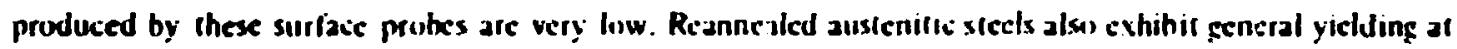
stresses which are low in relation io tl:c creep strength. approximateiy 70 .MPa in the teinperal ure range of 450 to $650^{\circ} \mathrm{C}$ (puni B). This seneral yiclding wiciurs hy planar slip. and in sniall-diameter lest hars

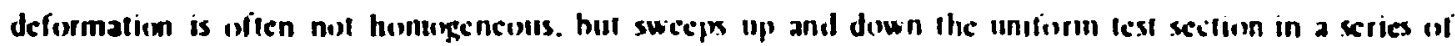

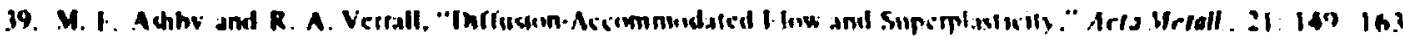
(197.3).

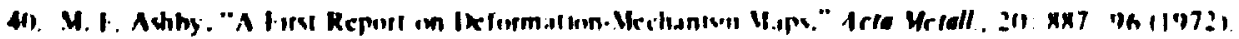

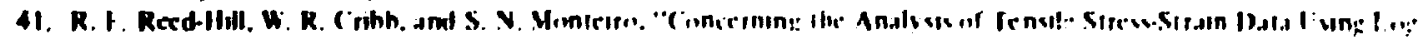

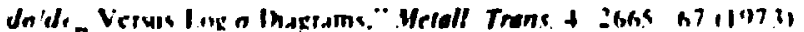

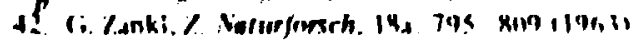

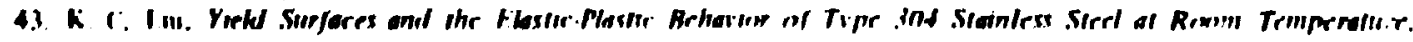
(IRNI /TY.\$421 II., the published)
} 


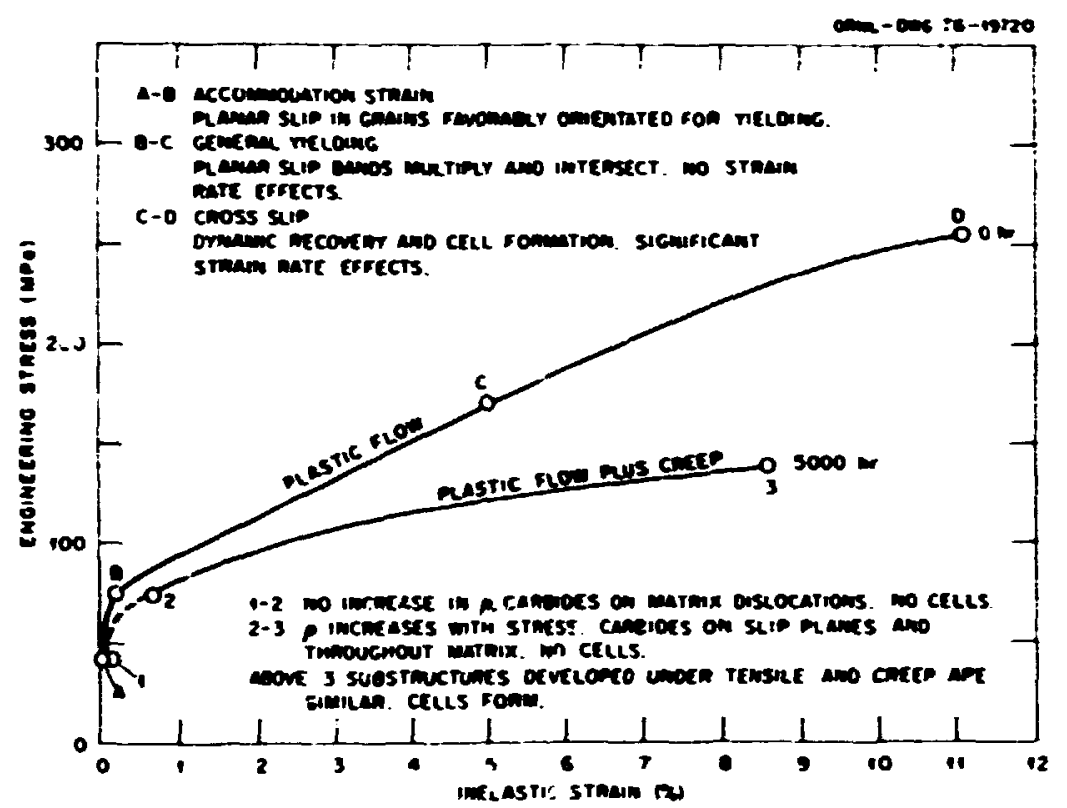

hr.

Fig. 40. Sembeructures developed in different rejions of the ibochronows stressincin cormes at $593 \mathrm{C}$ for 0 ad 5000

strain bursts. "4t is well established by Stiechen and other researchers $4,46.19$ that flow stress is relatively independent of strain rate, but possibly flow stress for type 304 stainless steel is inversely related to strain rate due to dynamic strain-aging pli.nomena. In other words, plasti: flow and hardening are essentially athermal for conditions of interest to most LMFBR plastic-flow problems." Any ur.tfied deformation model must account for this athermal condition. In contrast, many of the glide deformation models proposed in recent years ${ }^{10.1}$ ' make use of thermal.stress activation-analysis principles ${ }^{10.1}$ ' such 25 those developed from the work of Seeger" ${ }^{47}$ and others." ${ }^{49} .9$ These models will have to be modified to account for observed behavior.

The conditions under which planar slip gives way to cross slip (point C) have not been esiablished for our material, and work on this subject should be initiaced soon. We can expect, however, that as flow stress increases, and the plastic strain accumulates under either monotonic or cyclic-strain modes, significant dislocation interaction and tangling will develop at intersections of active slip planes. Cross-slip processes will be activated and dynamic-recovery processes will become significant. This change leads to cell and subgrain formation (C to D). It is consistcritly observed that as both stress and strain increase conditions are

44. D. Fahr, Andysis of Stress-Srmin Betovior of Type 316 Stoinless Sreel, ORNL.TM-4292, Oak Rivge Nalmnal Labortory November 1973).

45. J. M. Steichen, "Mathematiol Description of the Filevated Temperalure Flow Behaviof or Type 304 Slainless Sleel at High Strain Rates," J. Test. Eval., I: 520 (1973).

46. J. P. Hammond and V. K. Sikka. Hear.fo-Heal Varbofions of Torol Struin (ro S\%) at Discrere Siress Levels in Types 316 and 304 srdinkss Sreel from $2410316^{\circ}$ C, OKNL./NURF,G/TM-57, Oak Ridge Nalional Labnratory. (November 1976). p. 30.

47. A. Seeger, "The Mechanism of Gilde and Work Hardening in. FCC. and HCP Metals," pp. 243 . 349 in Dislocotions and Mechonical Properties of Crystals, ed., J. C. Fisher. Wiley and Sons, New York, 1957.

48. H. Conrad, "Thermally Activated Defurmation of Metals," J. Metals. 16: 582 .88 (1964).

49. R. W. Armstrong. "Thermal Activation Strain Rate Analysis (TASRA) for Polycrystalline Mgtals." Pp. $306-13$ in Defect Inreverions in Solds, eds. K. I. Vasa el al., Indian Institute or Science. Bangalore. 1972. 
approached where strain ate behavior under tensile ionditions cunturms to the expectations based on thermal-stress activation principles. The glide processes for flasticity and er-ep ibeconce one and the same. Muteif and coworkers 24.50 have established that the substruitures developed in high-stress tensile and creep tests are very simiiar.

Different ranges can also be identified in the $5000 \mathrm{hr}$ isoxhronous curve at $593^{\circ} \mathrm{C}$ lcurve $1.2-3$ in Fig. 40). In the stress range corresponding to the accommodation strain range. the creep strains are luw: no signifizant increase in the disloation density is observed, and no cells are developed. The major modification in the substructure due to erecp expusure is the precipitation of carbides on some dislocations. This precipitation influenoes the plastic-flow stress and creep behavior. In th: stress range where planar slip vecurs under plastic conditions (segment $2-3$ in Fig. 40 ). the creep strains atter 5000 hr become equivalent to or larger than the plastic loading strains. $\rho$ tends to increase with st ress. and again no cells form. Data available at 121 and 172 MPa suggest that the total disluation density does nut change greatly as a consequence of the accumulated creep strain. If this observation is true. further studies of the transition of substructure in the early stages of creep could te of benefit in understanding ireep-plasticity interactions. Clearly. cyclic loading must also be included in such an activity. At stresses where cruss slip and dynamic recovery are significant (beyond point 3). plasticity-produced and ireep-proxduced substructures are indistinguishable. Constitutive equations could be based on a rate type of approach.

Returning to low stresses. we now cousider how the substructure developed under plastic strain or creep inflences subsequent creep behavior. A logial focal point for such a conside:ation is the otten used Orowan exp:ession:

$$
\dot{\epsilon}=b \rho_{m} \mathbf{v}
$$

where $\dot{\epsilon}$ is the strain rate. $b$ is the Burgers vector. $\rho_{m}$ is the mubile dislocation density. and $r$ is the average dislocation velocily. Clearly. if the infroduction of plastic or creep sisain increases $\rho_{m}$. Hhe crecp rate will increase. assuming for the moment that the dislocation velocity is not influenced by the value of $p_{m}$. Unfortunately $\rho_{m}$ is not synonomous with ihe dislocation density reported in Table 1 . but is probably a function of the applied stress level. $\sigma_{a}$. As pointed uut by McLean ${ }^{31}$ and others: 5 a mobile dislocation at a high stress might not be mobile at a low stress. Odén et al.' " define a nobile dislucation as one which lias a length. I, so that

$$
1 \geq I_{n}=a G \mathbf{b} / \sigma
$$

where $I_{n}$ is a critical length given by the right-hand side of the equation. $G$ is the shear modulus. $\sigma$ is the stress on the dislocition. $b$ is the Burgers vector. and $a$ is a material constant. It has been shown by Odén et al. 7 that creep strains prodicie large incteases in the total dislocation density. hut significant decreases in the mobile dislocation density. Plastic strains are also known to increase the total dislocation density. and by implication the mobile dislocation density as defined by Odén el al. ${ }^{7}$ would decrease.

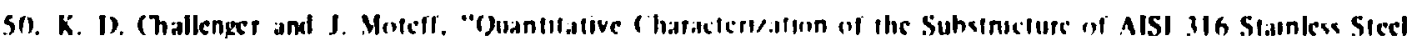
Resulting from ('recp." Mefall. Trans. 4: 749 \$s 1197 \}).

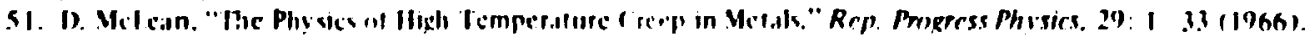

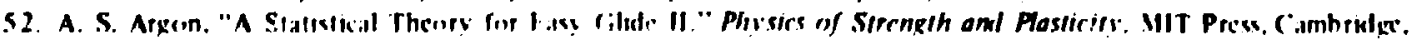
Mass.. 1969. $217 \quad 53$. 
Our data suggest a different trend, however. For example, $\rho$ does not seem 10 change greatly d::ring creep, and plasticity dues not seem to produce much hardening. In fact, some of our unpublished data show that small plastic strains can actually accelerate creep for a short time.

It is clear that the mobile distocation density. $\rho_{m}$, should be greatly influenced by the precipitation of the $\mathrm{M}_{2} \mathrm{C}_{6}$ carbide. The matrix carbide does not precipitate under very short time piasticity situations: hence, the strengthening when creep commences is primarily associated with the changes in the distocation configuration. Eventually. when the matrix carbide does develop. the fine precipitates observed at temperatures in the 538 to $621^{\circ} \mathrm{C}$ range immobilize by pinning many of the distocations having large values for L Further, the carbides appear 10 stabilize a fine distocation network, as discussed by Hopkin and Trylor, 33 and thus produce strengthening for both creep and plasticity situations. To make matters mure confusing. however, there seems to.be some evidence that the large blocky precipitates which form at $650^{\circ} \mathrm{C}$ and above can att as dislocation sources under thermal cycling conditions. 54

The mobile dislocation velocity term, $v$, in the Orowan, equation is thought to depend on temperature, stress, achivation volume, and total dislocation density. The specific formulation for $v$ depends on the detaiis of ire deformation mechanism. ${ }^{25}$ however, which we have not identified for our material. Velocity should incrusse with temperature and stress and decrease with the activation volume and total dislocation density. Depending upon the specific model, the substructure studies of the type performed here may be extended to provide data to estimate v. A closer coupling between experimental and andytical work would be required to produce anything truly useful, however. Because creep is a slow, more or less continuous process, it is easy to imagine dislocations moving at some average velocity and contributing to the total deformation. However, in the recent model developed by Lageborg." dislucations glide "rapidly" between arrested positions, and in this sense. deformation by creep and plaxticity $c$ suld be very similar. Without a sound knowledge of the precise mechanism it cannol be shown that the same constitutive relationships should apply to both loading situations. From an experimental viewpoint, the separation of creep and plasticity for low stresses seems justified.

Among the most often demonstrated correlations between substructural parameters and mechanical variables are the relations between stress and dislocation density and stress and subgrain (or cell) size. In Fig. 41, the siuare root of the disiocation density, $\sqrt{p}$, is plotted against the modulus-compensated true stress $(\sigma / G)$, using data frum Table 1 . Also included in the figure is a dashed trend line based on specimens tested at higher temperatures. 30 The line conforms to the observation that $\sqrt{\rho}$ is inversely proportional to the stress under steady-state creep conditions. It is interesting to note that data from Table I gemerally fall above the line, meaning that the dislocation densities are too high. The data in Table I have been obtained from specimens tested into different creep stages but also at temperatures generally below those used to develop the line. The reasons fot this difference have not been determined, but it does seem possible that the relation between $\sqrt{i p}$ and $(\sigma / C)$ could be temperature sensitive below $650^{\circ} \mathrm{C}$. If so, then there are some interesting implications. These come about if we accept the concept that an internal stress $\sigma_{1}$, exists so that

$$
o_{i}=a G B \sqrt{p}
$$

53. L. M. T. Hopkin and L. H. Taylor. "Creep Properties of Cr-Ni-Mn Austenitic Steel in Relotion to Structure." J. iron seed liner. 265, 17-27 (1967).

54. S. R. Keown, "Microstnctural Changes Occurring During the Creep Defomation of a Simple Austenitic Stecl at 600'C," pp. 78-85 in Creep Sirength in Sicel ent High.Tempenetwe Alloys, Metals Sociely. Inndon. 1974. 


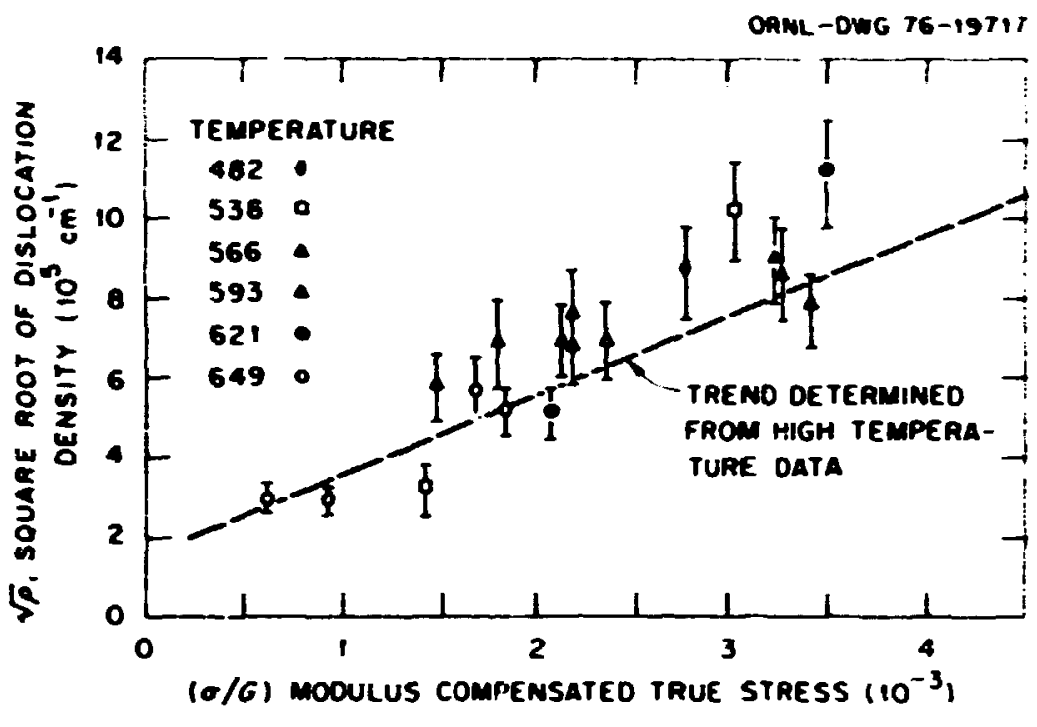

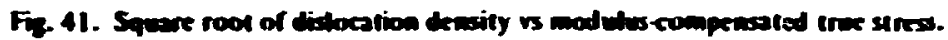

where $a$ is a mate ial constant whose value lies in the range 0.3100 .6 . Using internal-siress concepis. we assume that the effective stresi. $\sigma^{*}$. which produces detiormation. is yiven by

$$
\sigma^{*}=\left(\begin{array}{ll}
\sigma_{2} & \sigma_{i}
\end{array}\right)
$$

where $\sigma_{1}$ is the applied stress. By detinition, in E.q. (3), $\sigma_{1}$ is proppurtional to the $\sqrt{\rho}$. and by observation. $\sigma_{\perp}$

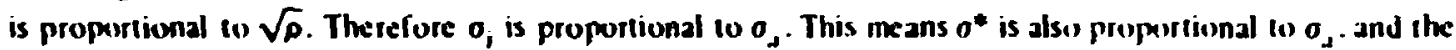

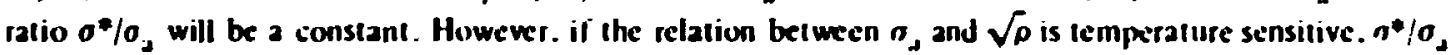
will also be temperature sensitive. which intuitively seems reasonable. We might expect that at low temperatures $\left(0^{*} / \sigma_{\lrcorner}\right)$should be small. and at high temperatures $\left(0^{*} / \sigma_{\text {J }}\right)$ should be large. Techniques for determining this ratio have been developed by Cuddy:"s Nix and Adguist." and Wilshire and coworkers. ${ }^{7.58}$ We have also planned experimental work in this area.

The steady-stale creep ratc. $\dot{\epsilon}_{5}$. is thought by some investigators to depend on $n^{*}$ acciording to the power law. Thus.

$$
\dot{\epsilon}_{、}=K\left(\sigma^{*}\right)^{n}=K\left(\sigma, \sigma_{1}, r\right.
$$

where $\mathcal{K}$ and $n$ are material constants. If a relationship such as that shown in Fy. $(5)$ really exists for creep. then an understanding of huw $O_{\text {, relates }} 10$ composition and substructure can be of considerable value in

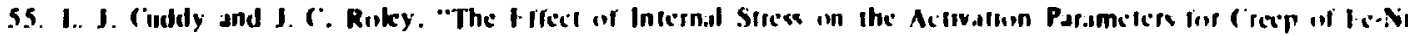
Alloys." Acro Mreall. $21: 427 \quad 33119731$

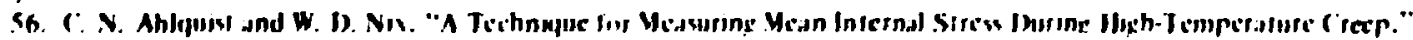
Scripre 1/rt. 3: $679 \times 2$ (196\%).

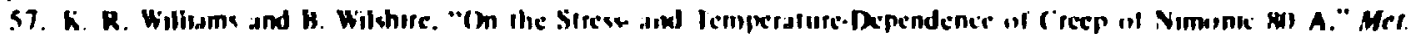
Sri. J. 7: 176 $79(1973)$.

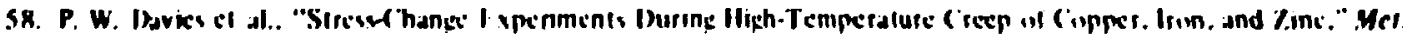
Sci. J. $7: 8792(1973)$. 
anderstanding hasdening and recorery concepts. In addition to a simple assessunent of the tural dislinazium line density. more detailed charsiterination of the dislocation network character can be of value. especially if the study is performed in conjunction with veriable toad tests which involve reciovery periods. ${ }^{17}$ and reversed stresses as ecuanined by Gillus."

The "ther microstrukitural correlation mentioned earlier involves the dependence of the cell or subgrain sixe. $\lambda$. On stress. According to the data of Challenger and Moteff ${ }^{34} .50$ and Sikka et al.."0 austenitic stainless steets follow one of two trends. Under high-stress munutunic and cyclic conditions where celts form, $\lambda$ is inversely proportional to the syure of the stress. At low stresses. $\lambda$ is inversely propurtional to stress. A comparison of dat? reported in Table $I$ to a previuusly determined relationship ${ }^{30}$ is shuwn in Fig. 42. These new data folluw the low-stress (tinear) trend. but tend to exhibit smalker cell and subzrain sizes than expected from earliet work.

Robinson and Sherby" have suggested that the subgrain sixe plays a significant role in the creep process. They have developed an expression for the steady-slate ereep rate in which subgrain size is explicitly included:

$$
\dot{\epsilon}_{s}=K(T)^{3}\left(\frac{O}{M}\right)^{T}
$$

where $M$ is the modulus, and $K$ is a temperature dependent consiant. Sincic the liwi-stress Jata for out material are inversely propostional to $\lambda$. the apparent exponent on the stress term should be reducied to 4

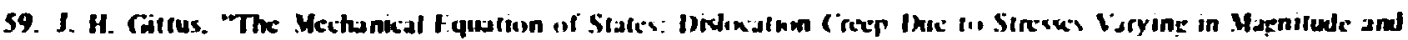

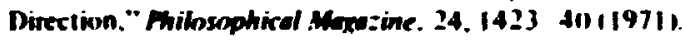

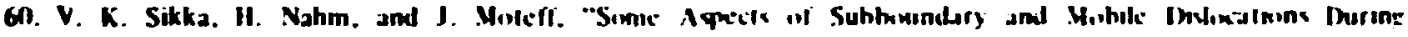

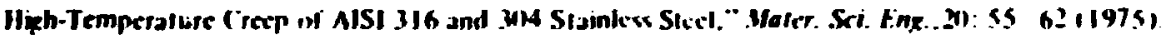

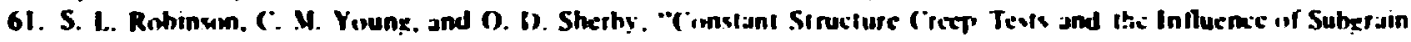
Sice on (reep." I. Morer. Sci., $9: 34143$ 1 1974$).$

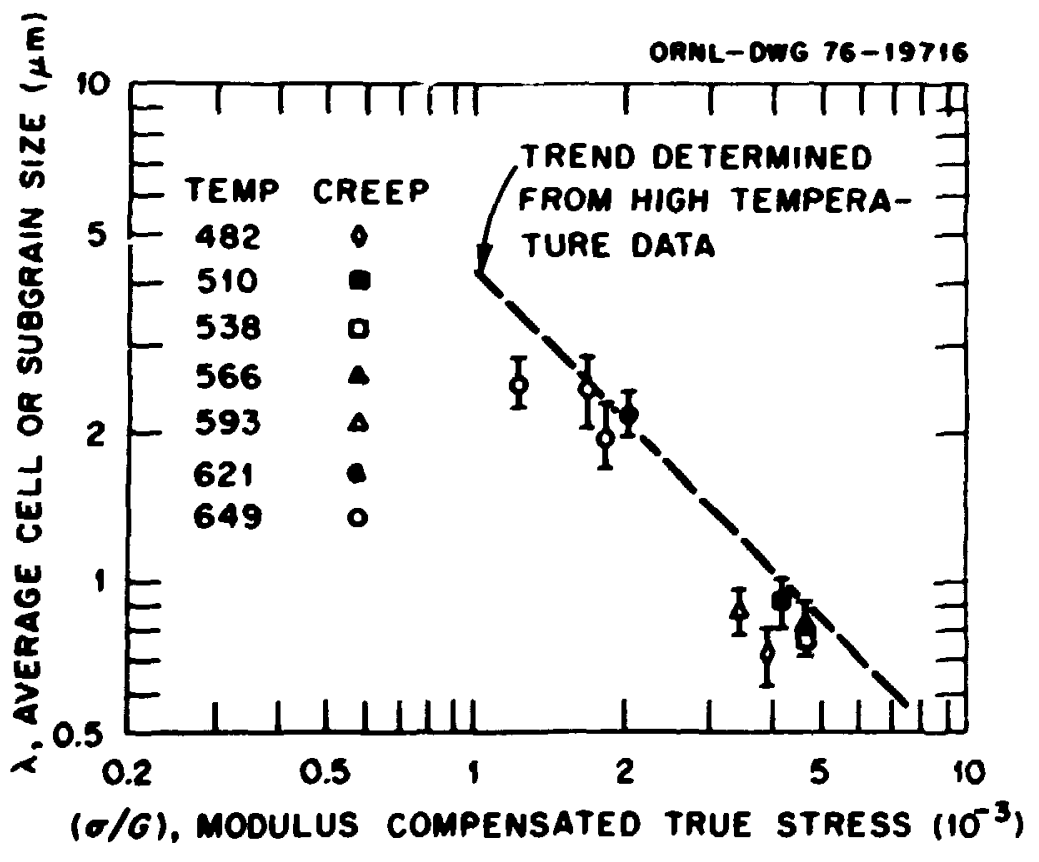

Fic 42. Antre cell of sobgrin sixe rs modulus-compensoled irue sires. 


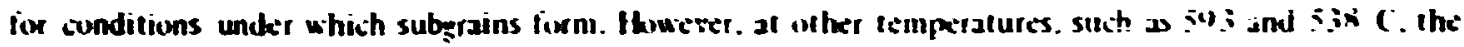
stress exponent shuuld remain at 7 . simic $\lambda$ is :instant and eyuivalent to the grain sice

Tixe formation of subgrains is also known to he:e a significant inlluencie on the skeld strength. $0_{2}$. especially at lower temperatures where the Hall-Peth relation ihip usually holds. Additunal studies by

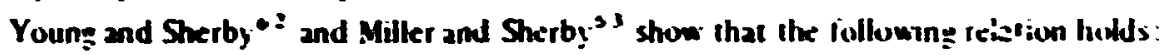

$$
\sigma_{y}^{2}=\sigma_{0}^{2}+k^{2} \lambda^{-2 m}
$$

where $n_{o}$. k. and $m$ are material constants. The applicability of this relallonshup io intermediate cemperalures should be examined sime it could be of value ir. undersianding the nature of creep-plasticit! interactions.

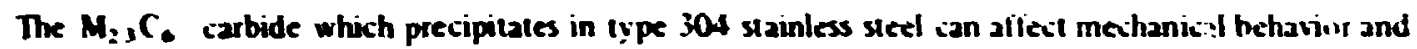
constitutive equation development in several ways. Cabon in sulution is knemn to be a potent strengthener in regard to plastic flow strengeth. ${ }^{3}$.64 Henie. depletion of this element could priducie lous in stretropth. In fact. the relativety fine dispersion which occurs at temperaiures in the range of 500 to b:50 C results in

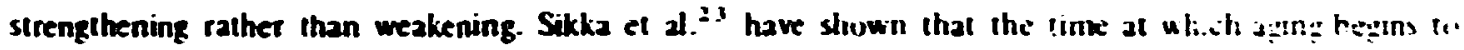
increase the flow stress corresponds to the time required fio the precipilation of nist nx carbldes. F ilennte et

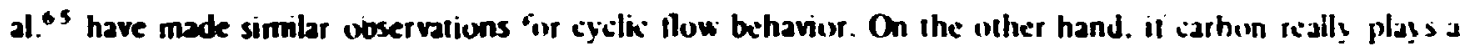
role in the strain-aging behavior, then the depletion of carbon could influenic the thiw-stress is strain-sate response in the temperature range of $35010650^{\circ} \mathrm{C}$. It must be recingnifed that the strainl-aging nethatior probably involves soluce elements as well as interstitials: therefore, strain aging should still he present dile:

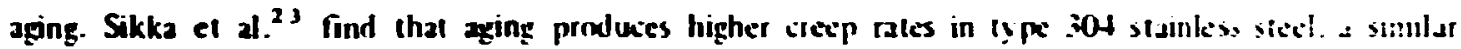

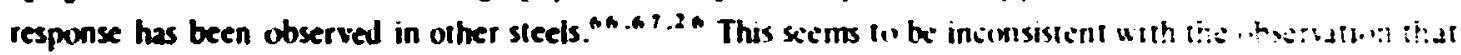

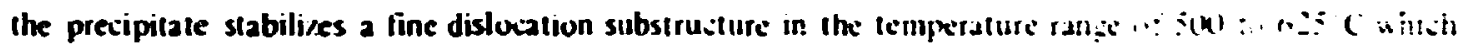

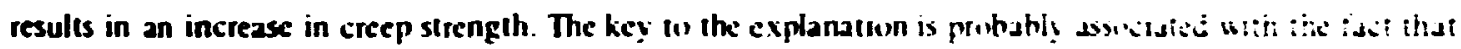

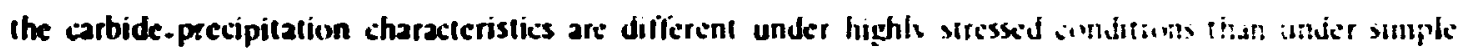
aging. It is well established that the kina :ios of the precipitation prociess ate influinied by the presenic of

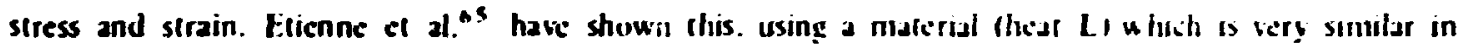
composition and strength to the imaterial we have studied. We have replieted their tume-remperature iransformation diagrams for low-siress aping in Figs. +3 and 44 . Fịure 4.3 shews the precipitation kanetics of matrix eabides with and without stress. The data unnlirm that high stresses acielerale both the start and the growth rate of the matrix carbides. especially at the higher leniperalures. Our investigations reveal that the carbides often delineate the planar-slip traces produced onl plastic leading alter the disliciations have climbed or cross slipped out of the planes and developed cellular configurations. Figure 44 shows the

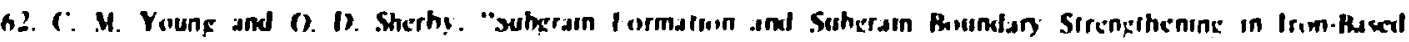
Vilcrials." J. Imm and Sirrl Inst. 2II: h\$ll $\$ 711973$,

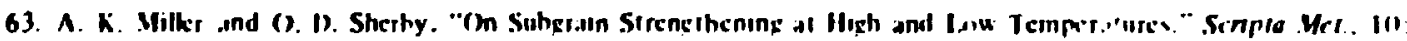
J11 1711976$)$.

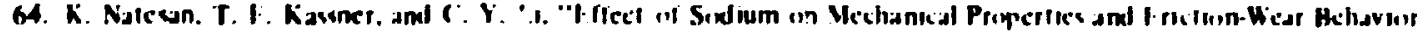

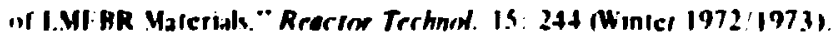

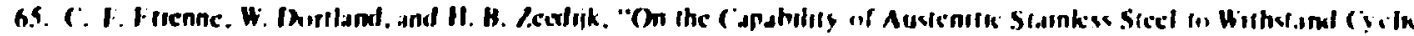

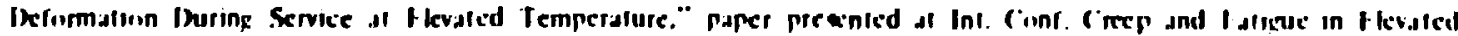
Temperalure Applicatuns. Mildacklphia. Seplember 1973. and I niferl kingdom. Sheffield. April 1974.

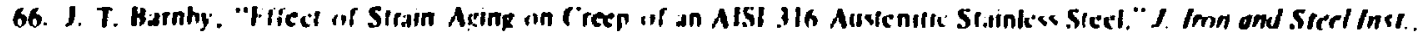
214: 2327 (1966).

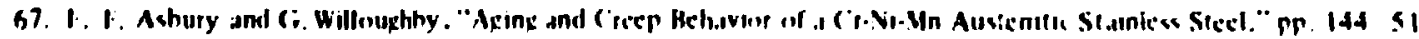

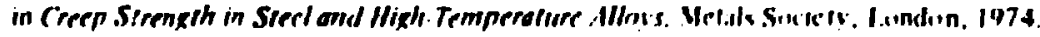




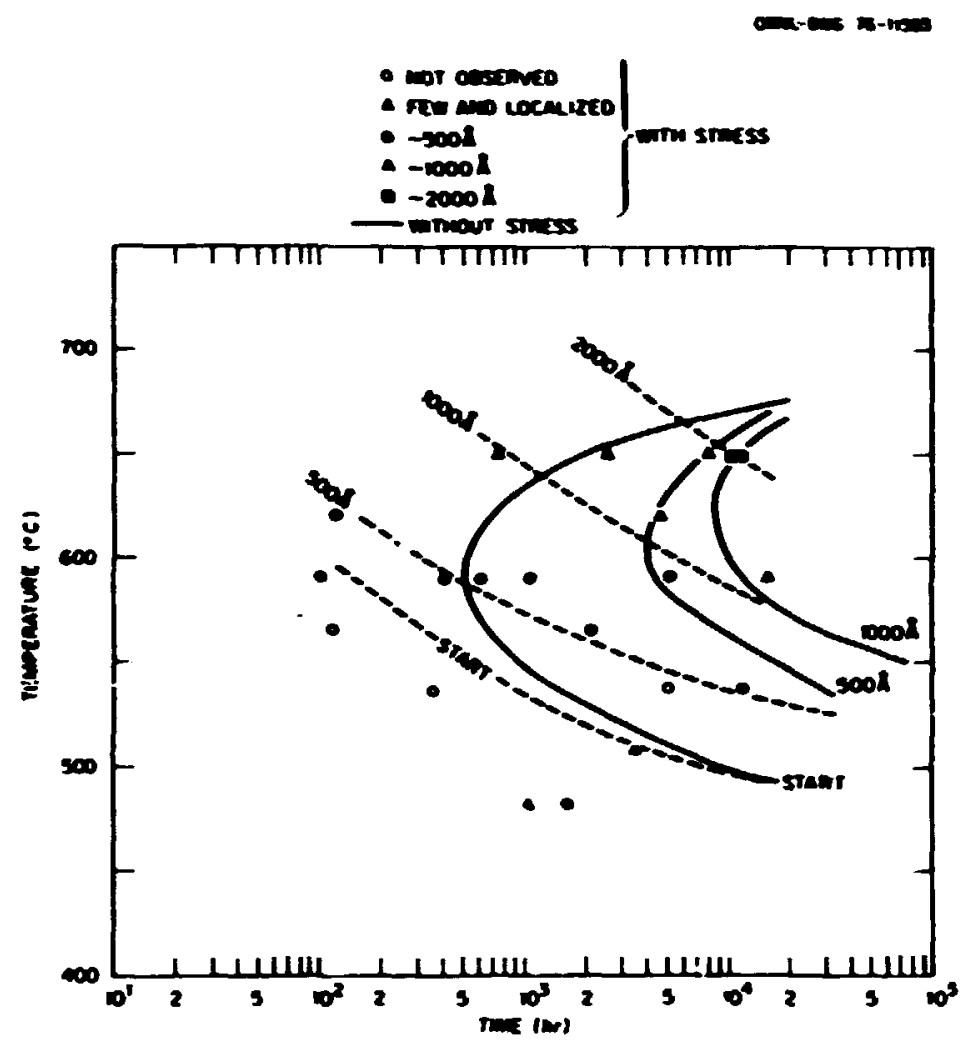

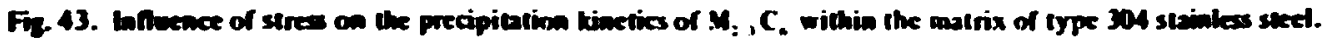

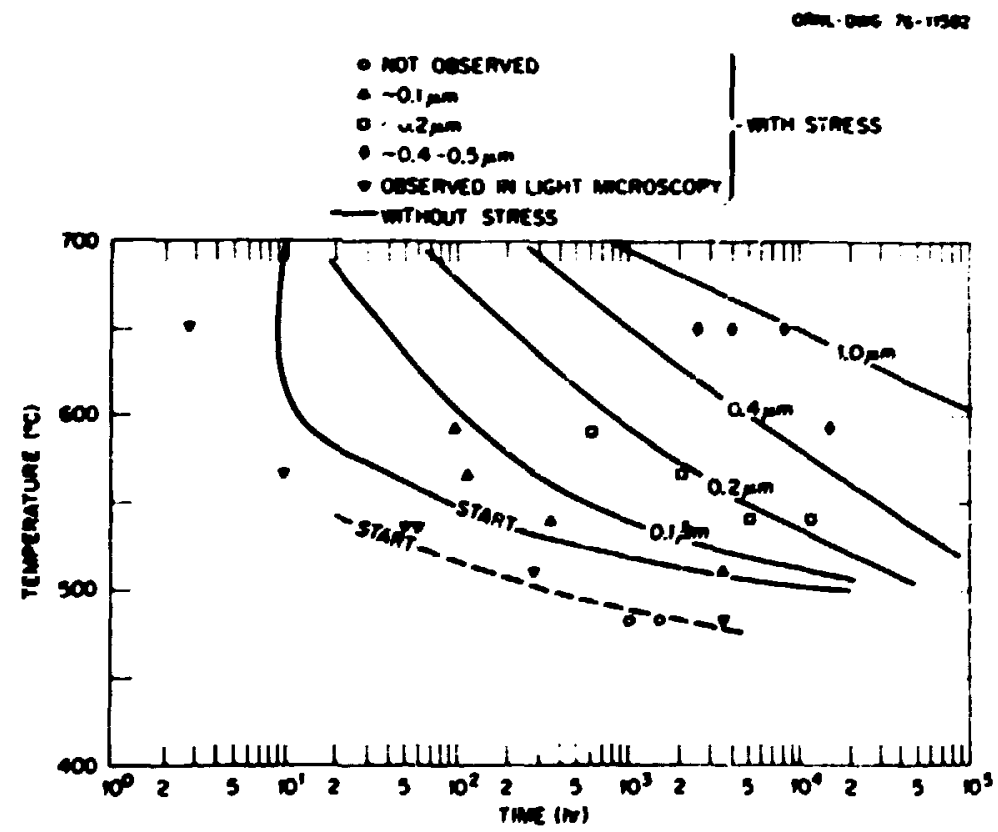

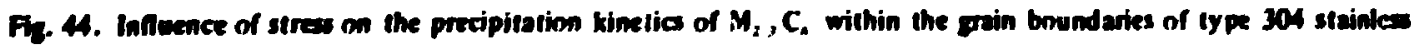
sud. 
precipitation kinetics of grain boundary carbides. In this case, the stress or strain seems i accelernte the start of the precipitation, especially at lower temperatures. The influence of grain boundary precipitates on the yield and flow betavior of our material has not been empiasized in this report. Actully, grain boundary carbides could play a sigaificant rok. At high temperatures the carbides precipitate quickly. and under some conditions denuding of arbon and chromium develops in zones on either side of the grain boundary. ${ }^{23.68}$ This relatively weak material could exhibit significantly different flow characteristics than the matrix away from the boundary does, and this possibility complicates efforts to describe hardening behavior. Under lower stress conditions, Keownsa observed that grain boundary carbides alter the dislocation's emitting or absorting the chanacteristics of the boundary. "s Further, the very presence of the precipitate complicates efforts to estimate the grain boundary diffusion contribution to creep, which has an impact on the position of the different fieds on the Ashby deformation map and thus compromises the uefulness of the approach.

In ail probability the carbide precipitation, especially on the grain boundaries, has an enormous influence on the rupture life and ductility. We have accumubted a significant body of data bearing on this subject for type 304 stainless steel. These data are currently being evaluated. As an example. in one study."9 the power law has been used to represent isothermal rupliure data in the lemperature range of 482 $10816^{\circ} \mathrm{C}$ :

$$
1 / t_{r}=(\sigma / A)^{n}
$$

where $A$ and $n$, are temperature-dependent constants which are determined by least syuares. Pluts for $A$ and $n$, aginst temperature are shown in Fig. 45. and it appears lial $n_{r}$ incieases with increasing temperature to nearly $600^{\circ} \mathrm{C}$ then decreases precipitously. The paak value of $n$, vicurs where the precipitate-dislocation interaction is most prominent.

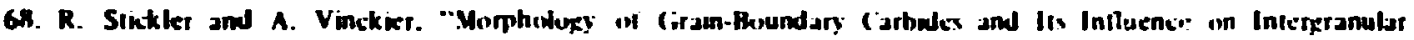
Corroxion of 304 Slainkess Sieel," Trens Amer. Soc. Mefals $\$ 4: 362119611$.

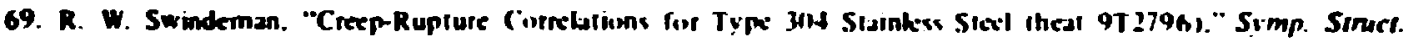

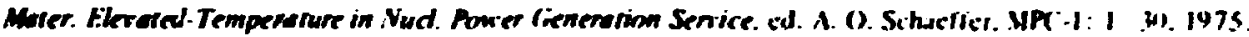

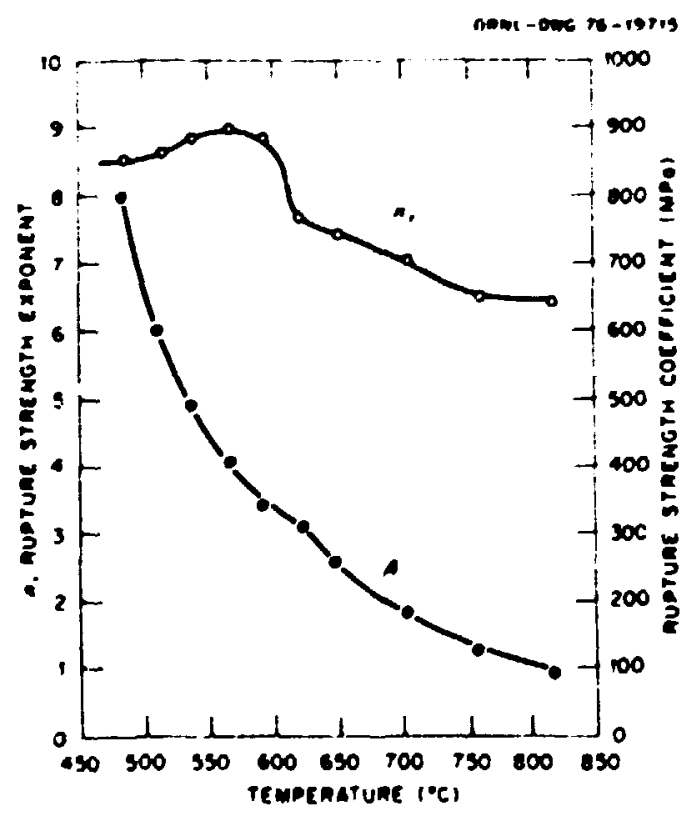

Fig. 45. Variation of $A$ and $n$, with temperature. 


\section{concussons}

1. At gresses which produce less then 15 zecumulated inelastic strair in 10,000 hr or less, the abserved distocation densities are close to the starting alue $\left(10^{\circ} \mathrm{cm}^{-2}\right)$. No evicence of cell formation exists. The major alerntion of substructure is the precipitation of $M_{2} C_{6}$ on grain toundaries, win boundaries, and on some distocations. This peccipitation is observed in the temperature range 538 to $649^{\circ} \mathrm{C}$.

2. At stresses which produce greater than is accumulated inetestic strain in $10000 \mathrm{hr}$ or less. the observed distocation densities and seltstructures depend on the temperature and stress kevel.

3. Al stresses in the range 69 to $172 \mathrm{Mr}$, and for temperalures in the range 482 to $593^{\circ} \mathrm{C}$, the observed distocation density tends to increase with increasing streses. To a first approximation the demity increases with the square of the stress. Dislocation densities are grater than expected based on studies at comparable stresses and higher temperatures, however. No evitence of cell formation exiuts: rather. dislocations are arranged in fairly fine networks and sometimes in dense tandes, which appear to be stabilized by fine precipitates.

4. At stresses in the range of 69 to $172 \mathrm{MPA}$, and for temperatures above $593^{\circ} \mathrm{C}$, the observed dislocation densities increase, approximately with the square of the stress. The cell size is inversely proportional 10 the stress. The cells are well dereloped and could be classified as a unixed configuration or even as subgrains in some cases.

5. At stresses above $172 \mathrm{MPz}$, and for temperalures in the range $48210649^{\circ} \mathrm{C}$, dislocation densities are very high and difficult to evaluate. Cells divelop whose walls cussist of dislocation tandes. The cell size is inversely proportional to the stress. but tends to be finer than th: cell size determined at simulat stresses but at higher temperatures.

6. Substructures developed under cyclic plasticity condit ons vary in character with the temperature. At 427 and $482^{\circ} \mathrm{C}$, dislocations are often arranged in primitive cells or bundles. The dislocation densities fall within the scatter band exhibited by monotonic data. :imilarly, the cell sizes fall within the scatter band for monotonic data. At $649^{\circ} \mathrm{C}$, the substructure is scmewhat variable. exhibiting some regions of primitive cells and other regions of faity well-defined cells. The dislocation densities and cell sizes are in agreement with the trends established from high-temperature data.

7. Exposure to creep conditions accelerates the growth of $M_{2} C_{6}$ carbides in the matrix, especially at higher temperatures. It also accelerates the start of preapitation of grain bourdary carbides at all temperatures.

8. The substructural data developed here do not refute the current constitutive equations which treat plasticity and creep strain separately with resfect to yield. f. ow. and hardening behavior. There is an urgent need, however, to perform more studies on tensile and creen tested specimens in the early stages of hardening. More study of substructures produced under cyclic-plasticity and cyclic-creep cunditims are also needed.

\section{ACKNOWLEDGMENTS}

The authors thank H. E. McCoy. Jr., R. L. Xing. C. R. Brinkman, and G. M. Staughter for review and helpful discussions. Ascisting in the report prepantion were Carolyn Strizak and the Technical Publications Department. The unnumbered iransmissionelectron micrographs in this report were provided by the University of Cincinnati in conjunction with their subcontract. 